IZA DP No. 9985

Neighborhood Effects, Peer Classification, and the Decision of Women to Work

Nuno Mota

Eleonora Patacchini

Stuart S. Rosenthal

June 2016 


\title{
Neighborhood Effects, Peer Classification, and the Decision of Women to Work
}

\author{
Nuno Mota \\ Fannie Mae \\ Eleonora Patacchini \\ Cornell University \\ and IZA
}

Stuart S. Rosenthal

Syracuse University
Discussion Paper No. 9985
June 2016

IZA

P.O. Box 7240

53072 Bonn

Germany

Phone: +49-228-3894-0

Fax: +49-228-3894-180

E-mail: iza@iza.org

Any opinions expressed here are those of the author(s) and not those of IZA. Research published in this series may include views on policy, but the institute itself takes no institutional policy positions. The IZA research network is committed to the IZA Guiding Principles of Research Integrity.

The Institute for the Study of Labor (IZA) in Bonn is a local and virtual international research center and a place of communication between science, politics and business. IZA is an independent nonprofit organization supported by Deutsche Post Foundation. The center is associated with the University of Bonn and offers a stimulating research environment through its international network, workshops and conferences, data service, project support, research visits and doctoral program. IZA engages in (i) original and internationally competitive research in all fields of labor economics, (ii) development of policy concepts, and (iii) dissemination of research results and concepts to the interested public.

IZA Discussion Papers often represent preliminary work and are circulated to encourage discussion. Citation of such a paper should account for its provisional character. A revised version may be available directly from the author. 
IZA Discussion Paper No. 9985

June 2016

\section{ABSTRACT}

\section{Neighborhood Effects, Peer Classification, and the Decision of Women to Work*}

We examine the influence of neighborhood peer effects on the decision of women to work using panel data that follows clusters of adjacent homes between 1985-1993. Modeling assumptions imply rank order restrictions that enable us to classify individuals into peer groups while identifying peer effects and underlying mechanisms. For women, peer effects influence labor supply in part because women appear to emulate the work behavior of nearby women with similar age children. For men, peer effects are mostly absent, consistent with inelastic work decisions. Geographically concentrated panel data are crucial for these estimates. Our approach could also be applied to other instances in which neighborhood peer effects are important.

JEL Classification: R2, J2

Keywords: neighborhood peer effects, female labor supply

Corresponding author:

Eleonora Patacchini

Department of Economics

Cornell University

Ithaca, NY 14853

USA

E-mail: ep454@cornell.edu

\footnotetext{
* We thank seminar participants at the London School of Economics, UCLA, Carleton University, and the 2014 Urban Economic Association meetings for helpful comments. All errors are our own.
} 


\section{Introduction}

Neighborhood peer effects have been notoriously difficult to identify despite numerous attempts to do so in the literature. This has been true regardless of whether the focus is on crime, school performance, employment, or a variety of other important outcomes. Equally challenging has been to provide evidence of the mechanisms by which peer effects are transmitted. These difficulties arise in part because individuals may endogenously choose their residence so as to be close to peers, and also because peers themselves are often difficult to define a priori. ${ }^{1}$ This paper makes progress on both fronts using a new approach that enables us to make two broad sets of contributions. The first is methodological as our research design could be used to address neighborhood peer effects in other settings. The second is contextual as we use our model to provide new insight into the influence of neighborhood peer effects on female labor supply.

Our focus throughout is on whether women age 25 to 60 choose to work, and whether the peer and work status of neighbors in adjacent homes affects that decision. For these purposes, an individual is said to work if they have positive earnings in the previous twelve months. ${ }^{2}$ For women, this is an active choice which suggests that peer effects could be relevant. For men the decision to work as defined here is largely inelastic and for that reason we expect peer effects to be small or absent. This enables us to use men as a falsification check on our model design. In all cases estimates are obtained using the 1985-1993 neighborhood cluster files of the American Housing Survey (AHS). These data follow groups of adjacent homes over time and provide temporal variation on target individuals and their neighbors that is essential for identification. ${ }^{3}$

\footnotetext{
${ }^{1}$ For recent reviews of the neighborhood and peer effects literature see Ioannides and Loury (2004), Granovetter (2005), Ioannides (2012), and Topa and Zenou (forthcoming). For a critical review of models and methods that have been used to analyze neighborhood effects see Gibbons et al (forthcoming).

${ }^{2}$ We also perform all of our analysis defining the decision to work based on higher earnings thresholds, select results for which are discussed later in the paper.

${ }^{3}$ Few previous studies have taken advantage of the AHS neighborhood cluster files. Among those that have, Ioannides and Zabel $(2003,2008)$ also use the AHS cluster files to examine evidence of neighborhood effects. In
} 
Central to our approach is a modelling structure that reverses the emphasis of assumptions and estimation found in most previous studies of neighborhood peer effects. Whereas previous studies assume a peer group based on race, gender, or some other trait, and then look for evidence of peer effects, we assume that peers affect each other through role model effects and/or information spillovers and then look for classifications of individuals that exhibit behavior consistent with being a peer. Shifting emphasis in this fashion enables us to provide evidence of peer effects and remarkably, underlying mechanisms, while also highlighting the importance of the peer classification itself.

We begin by assuming that role model effects cause women to emulate the behavior of nearby peers regardless of whether those peers work or do not work. We also assume that wordof-mouth information about job opportunities is enhanced most by proximity to working peers, less so by proximity to working non-peers, and even less by proximity to non-working neighbors regardless of peer status. ${ }^{4}$ These assumptions imply rank order restrictions on model coefficients associated with the impact of working and non-working peers and non-peers. Working peers should have the largest positive effect on a woman's propensity to work because of reinforcing effects of role models and information networks. Non-peers should have smaller effects regardless of their work status. Non-working peers should have the largest negative effect on a woman's decision to work because of the assumed dominant influence of role model effects.

Drawing on these rank order restrictions it is possible to discriminate between alternative classifications of peers. As a benchmark, random assignment of neighbors as peers and non-

their work the focus is on housing demand and home maintenance and relies on a very different identification strategy than here.

${ }^{4}$ In related work, Calvo-Armengol and Jackson (2004) model the impact of a network of contacts on the employment outcomes of an individual. In their model agents are randomly presented with job offers which they can choose to take or pass them on to other network members. Therefore, the better your network is, in terms of better employment matches, the more likely it is information on job offers will be passed on to you. 
peers would make the peer distinction meaningless which should cause the coefficients on proximity to peers and non-peers to be similar. On the other hand, provided peer effects exist, peer classification schemes that capture how peers are perceived should support the rank order of coefficients described above while maximizing the difference in coefficient values associated with working and non-working peers.

In total, we experiment with thirteen peer definitions from broad to very refined. In all cases, peers are defined as individuals who share the same demographic traits as the target individual based on combinations of gender, age of children, education, and marital status. Our most exacting peer definitions allow for up to thirty-six different types of people, only one of which is a peer for a given individual. For such refined classifications it seems unlikely that an individual would know whether a prospective adjacent neighbor was a peer before moving into a home. It is even less likely that an individual would choose a residence in anticipatation of a specific change in the peer and work status of adjacent neighbors. This, along with inclusion of person fixed effects (which control for time invariant person, house, and neighborhood attributes) helps to mitigate any possible endogenous sorting of individuals into neighborhood clusters. Moreover, the peer and work status of adjacent neighbors exhibits considerable temporal variation that is essential for estimation of the model. That variation arises from changes in the attributes of the target individual that affect a person's type (e.g. the birth of a child), changes in the attributes of neighbors who remain in the community between surveys, and in- and out-migration of neighbors from the cluster.

An additional modeling assumption has important implications for implementation of these models. Adjacent peers may provide valuable connections to a geographic community that extends beyond the neighborhood cluster but which also affects an individual's work status. 
This could occur through school, church or other community organizations, and implies that the work status of peers and non-peers throughout an individual's metropolitan area may influence a target individual's work status. To allow for this possibility, in our most robust models we proxy for the actual work status of adjacent peers and non-peers using peer-specific MSA-level employment rates for the survey year in question (in a manner to be clarified later in the paper). This has the added advantage of addressing three other empirical concerns that could threaten identification. Specifically, proxying as just described eliminates possible effects of unobserved neighborhood-level labor demand shocks that would affect the work status of all neighborhood residents, and also simultaneous feedback between the work status of adjacent neighbors and the work status of the target individual. It also mitigates attenuation bias that would arise if a neighbor's work status is misreported or not indicative of their usual activity.

Results from a variety of model specifications indicate that neighborhood peer effects influence a woman's decision to work and that this occurs at least in part because women emulate the work status of nearby role models. In this context, other women with similar age children appear to be most important as peers. Our most reliable estimates indicate that adding one additional working peer to a women's adjacent neighbors increases her tendency to work by 4.5 percentage points. Adding a non-working peer reduces her tendency to work by 9 percentage points. Adding working and non-working non-peers to a women's adjacent neighbors has little influence on her decision to work.

For men, simply specified models yield estimates of positive peer effects, contrary to our priors and suggestive of positive local labor demand shocks that affect employment throughout an individual's neighborhood cluster. Evidence of male peer effects disappears, however, when we proxy for neighbor work status using MSA-level peer- and non-peer specific employment 
rates. These patterns underscore the need to provide robust controls for localized time-varying labor demand shocks and also provide support for our research design.

Our modeling strategy and data structure differ markedly from recent state-of-the-art efforts in the neighborhood and peer effects literature. One important class of studies, for example, draw on survey-based data that explicitly identify the structure of peer-based networks, as with friendship networks that document who is friends with who from among a group of individuals. Recent papers of this type include Bramoullé et al. (2009); Liu and Lee (2010), Calvó-Armengol et al. (2009), Lin (2010), Lee et al. (2010) and Liu et al. (2012). These studies typically draw on idiosyncratic features of the friendship network to identify peer effects, in conjunction with the use of the characteristics of friends of friends as instruments to tackle lurking concerns about endogenous membership in the network. ${ }^{5}$

A different approach is exemplified by two recent studies by Hellerstein et al (2011, 2014). These studies rely on confidential versions of the US LEHD employer-employee matched panel data that identify the individual as well as the identity of the employer. Residential and work place locations are reported at the census tract level. Using these data, Hellerstein et al (2014) control for person and employer fixed effects as well as census tract measures of proximity to co-workers in the residential community. Their results indicate that the presence of a larger number of co-workers in an individual's residential census tract is associated with reduced job turnover. Hellerstein et al (2014) interpret this as evidence of improved wordof-mouth labor market networks that result in better matches between employers and workers. ${ }^{6}$

\footnotetext{
${ }^{5}$ Additional studies of this type include Asphjell, Hensvik, and Nilsson (2013) who examine the timing of child bearing among women who work for the same employer, Cappellari and Tatsiramos (2010) who consider labor market outcomes among close friends, and Cingano and Rosolia (2012) who estimate reemployment rates among individuals displaced from the same company. All of these studies report evidence of peer and network effects. ${ }^{6}$ In many respects, the Hellerstein et al $(2011,2014)$ papers build off of recent work by Bayer et al (2008). Bayer et al show that two individuals who live on the same census block are more likely to work together than if they live in the same group of roughly ten census blocks and that this pattern is even stronger among individuals of similar race
} 
A third recent approach to identification of neighborhood effects relies on experimental and pseudo experimental data in which individuals are randomly assigned to different neighborhoods. An example of the former includes Kling et al (2007) who analyze data from the Moving To Opportunity (MTO) experiment conducted in five U.S. cities by the US Department of Housing and Urban Development (HUD). ${ }^{7}$ An example of the latter includes recent studies by Damm $(2009,2014)$ who evaluates the impact of random assignment of immigrants in Denmark into different neighborhoods around the country. Broadly speaking, a series of studies based on the MTO experiments have generally failed to find compelling evidence of neighborhood effects for most types of outcome measures (e.g. criminal activity, teen pregnancy, school achievement). Damm $(2009,2014)$, however, does find evidence that proximity to employed individuals of one's own ethnicity increases the tendency for a recent immigrant to be employed. She interprets this as evidence of neighborhood-based word-of-mounth job networks that help immigrants secure employment. ${ }^{8}$

Relative to these and other studies, the data structure in the AHS neighborhood files is unique in that it follows hundreds of clusters of 8 to 12 adjacent homes over time. The extreme proximity of homes within a cluster along with the panel dimension allows us to achieve many of the advantages of random assignment data. On conceptual grounds and also based on diagnostic tests reported near the end of the paper, we argue that such temporal variation in proximity to peers is exogenous after conditioning on person fixed effects and more traditional controls.

and ethnicity. They interpret their results as evidence of word of mouth labor market network effects. Weinberg et al (2004) also uses detailed individual-level data from the NLSY to identify evidence of peer and network effects in labor markets.

${ }^{7}$ The program issued housing vouchers to participating low-income households, some of whom were issued Section 8 vouchers as a control group while the target group were randomly assigned to select neighborhoods (see http://portal.hud.gov/hudportal/HUD?src=/programdescription/mto for details).

${ }^{8}$ In related work, Beaman (2012) examines the labor market outcomes of political refugees assigned to communities across the United States. She finds that larger numbers of nearby recently assigned refugees hurts refugee labor market outcomes which she attributes to a competition effect. The presence of more established immigrants from the same country enhances refugee labor market outcomes, consistent with a positive labor market network effect. 
Three important messages emerge from our study. The first is that women appear to be sensitive to role model effects of nearby peers when deciding whether to work. We believe this evidence is new to the literature while echoing recent work in economics on cultural drivers of female labor supply that draws on behaviorially-based arguments from sociology and psychology (e.g. Alesina et al. (2013), Fernandez, Fogli and Olivetti (2004), Fogli and Veldkamp (2011), Olivetti, Patacchini and Zenou (2013), and surveys by Bertrand (2010) and Fernandez (2011)). ${ }^{9}$ A second message is that evidence of peer effects requires proper assignment of individuals into peer groups. In the absence of clear priors about the nature of a peer group, it is desirable to let the data identify peer classification schemes in conjunction with the sort of modeling structure used here. This point is relevant to other contexts outside of labor supply in which peer effects are important. Our third message is that geographically concentrated panel data such as the AHS neighborhood cluster design provide a different and valuable opportunity to identify peer effects.

We proceed as follows. Section 2 describes the data. Section 3 outlines our conceptual model and identification strategy. Section 4 discusses summary measures and results, and Section 5 concludes.

\section{Data}

Data for the analysis are taken from the national core files and neighborhood supplement of the 1985, 1989, and 1993 waves of the American Housing Survey (AHS) panel. Each survey contains an extensive array of questions about the house, neighborhood, and occupants. The survey is designed to be approximately representative of the United States and yields a panel that

\footnotetext{
${ }^{9}$ Collectively, these studies argue that gender norms and attitudes are important drivers of heterogenous patterns of female labor supply across countries, ethnicities, and generations. Fogli and Veldkamp (2011), for example, argue that women learn about the effects of maternal employment on children by observing nearby employed women.
} 
is unique among major surveys in that it follows homes not people. The national core survey is conducted every odd year (e.g. 1985, 1987 ...) and collects data from occupants of roughly 55,000 homes. The neighborhood supplement survey was only conducted in 1985,1989 , and 1993, and targeted the 10 nearest neighbors of 680 AHS core houses, henceforth referred to as neighborhood clusters. The exact number of units surveyed varies across years because of budgetary and other considerations (see the Codebook for the AHS, April 2011 for details). As would be expected, few homes are present throughout the entire panel. Instead, homes enter and leave the survey at different times but not in a manner that likely biases our results. ${ }^{10}$

Although the initial 1985 survey included 680 clusters, the pooled sample across survey years contains 737 different neighborhood clusters spread across 112 metropolitan statistical areas (MSAs). We initially restrict this sample to adults between 25 and 60 years old which leaves 6,470 men and 7,273 women spread over 725 and 728 clusters, respectively (see the bottom of the first two main columns in Table1a). Our estimating sample is further restricted to individuals who are present in at least two consecutive surveys and who are between ages 25 and 60 in both survey years. This yields a sample of 2,272 men and 2,608 women with a total of 5,409 and 6,252 male and female person-year observations, respectively (see the bottom of the two far right columns in Table 1a). It is this sample that is used to define our dependent variable. When measuring the average attributes of adjacent neighborhood peers and non-peers we use a similarly age-restricted sample but in this case include all individuals who are present in a given survey year regardless of whether the neighbor in question is present in one or multiple surveys.

\footnotetext{
${ }^{10}$ The AHS is designed and implemented by the Department for Housing and Urban Development (HUD). Conversations with HUD officials confirmed that the composition of the AHS sample is adjusted over time to help ensure that it remains roughly representative of the U.S. For a succinct comparison of the sample design and coverage of the American Housing Survey (AHS), the American Community Survey (ACS), and the Current Population Survey (CPS) see http://www.census.gov/housing/homeownershipfactsheet.html. Additional details of the AHS sample design are provided in the codebook manuals listed in the reference section of this paper. Ionannides and Zabel (2003) also provide detailed summary measures on the AHS cluster files.
} 
Table 1a reports summary statistics on individual and neighborhood attributes for individuals age 25 to 60 who are present in at least one survey, and individuals age 25 to 60 who are present in at least two consecutive surveys (and within the age target in both instances). Note that the summary measures are quite similar for the two samples although individuals present for two or more consecutive surveys are somewhat more likely to be married.

We define our dependent variable as 1 if an individual reports positive earned income in the previous year and 0 otherwise. Based on this definition, 89 percent of men in the estimating sample worked in the previous year while 69.7 percent of women worked (see the top of Table 1b). We have also run our models using $\$ 5,000$ (year-2013 dollars) as the cutoff to define work status. Selected results from those models are presented later in the paper. Additional models were also run with income cutoffs all the way up to $\$ 50,000$ (year-2013 dollars). As the earnings threshold rises beyond $\$ 5,000$ results change in ways that are difficult to interpret because of the combined effects of the decision to work, hours worked, and hourly wage (a proxy for skill). Only when we adopt a zero-earnings threshold do we isolate the decision to work. For that reason and also because the decision to work is especially relevant for women we favor the zero income threshold.

Finally, as discussed earlier, in our more robust models we proxy for a neighbor's actual work status using MSA level peer and non-peer specific employment rates. In this context, peer groups are based on a collection of demographic attributes that are used to define peer and nonpeer neighbors; for example, a female with a high school degree, single, and with one child under age 5. MSA-level employment rates for all of the peer types used in the study are obtained from the Current Population Survey (CPS), March supplement for the years 1985, 1989, and 
1993. As with the AHS data, in all cases, we measure employment rates in the CPS based on whether a given individual earned positive income in the previous year.

\section{Model and identification of peer effects}

This section outlines our conceptual model and related testable hypotheses. We also describe the econometric specifications and indentification strategy.

\subsection{Conceptual framework and testable hypotheses}

Suppose initially that peer effects are the only systematic driver of an individual's decision to work and consider a community populated with two types of individuals, A and B. Individuals within each group view each other as peers and within each group some individuals work while others do not. Peers are assumed to share information on job market opportunities more readily than do non-peers. Peers also serve as role models for each other, emulating each other's behavior. While this can also occur between non-peers we assume it does so to a lesser degree.

Our regression models all contain variants of the following general expression,

$$
\text { work }_{i, n}=\theta_{1} W P_{i, n}+\theta_{2} W N P_{i, n}+\theta_{3} N W N P_{i, n}+\theta_{4} N W P_{i, n}
$$

where work equals 1 if individual $i$ in neighborhood $n$ works and 0 otherwise, WP is the number of nearby working peers, $W N P$ is the number of nearby working non-peers, $N W N P$ is the number of non-working non-peers, and NWP is the number of non-working peers. In viewing (3.1), suppose initially that individuals are randomly assigned to their neighborhoods and that the only systematic determinants of whether an individual works or does not work are the peer and nonpeer variables in (3.1). Because information spillovers and role model effects both contribute to 
the positive effect of working peers on an individual's propensity to work, $\theta_{1}$ should be especially large and positive. Information spillovers and role model effects may also contribute to a positive influence of working non-peers on an individual's propensity to work, but to a lesser degree. Regardless of peer status, non-working neighbors are expected to contribute relatively little information about job market opportunities. Proximity to non-working individuals also has a negative role model effect that is assumed to be especially strong for nonworking peers. Summarizing, these modeling assumptions imply that,

$$
\theta_{1}>\theta_{2} \geq 0 \geq \theta_{3}>\theta_{4}
$$

The inequalities in (3.2) provide a set of testable relationships that are potentially revealing of neighborhood effects and of the mechanisms that contribute to those effects. Evidence, for example, that $\theta_{4}$ is negative and more so than the other coefficients would be indicative of negative role model effects. That is because we assume that non-working peers have non-negative effects on an individual's access to information on job opportunities and that role model effects are stronger within as opposed to between peer groups. If $\theta_{4}$ equals zero and $\theta_{1}$ is positive and larger than the other coefficients, that would be consistent with the presence of word-of-mouth job market networks and related information spillovers as emphasized in Hellerstein et al (2014) and Damm (2014). If instead $\theta_{4}$ is strongly negative and $\theta_{l}$ is strongly positive (in the sense of the inequalities in (3.2)), then the positive coefficient on $\theta_{1}$ would be consistent with the presence of positive peer effects arising from either information spillovers, role model effects, or both.

\subsection{Empirical model}

Our challenge in testing the restrictions implied by (3.2) is to obtain consistent estimates 
of the peer and non-peer coefficients allowing for the influence of other drivers of whether an individual works and the possible endogenous sorting of individuals into their housing cluster. We begin by drawing on the panel feature of the data. For those homes that do not turn over between surveys we follow the individual occupants over time which enables us to include person fixed effects, $\delta_{i}$. The fixed effects sweep out the influence of time-invariant individual, house, and neighborhood cluster attributes. Additional time varying individual and cluster attributes are represented by the vectors $X_{i, t}$ and $X_{n, t}$, respectively, where $t$ denotes the time period in question. Also included in the model are year fixed effects, $\delta_{t}$, and controls for the MSA-level employment rate in a given survey year, $E_{t, n}$, the specific form for which differs depending on other features of the model (in a manner to be clarified later). Adding these controls to (3.1), our regression models are of the following general form,

$$
\begin{aligned}
\operatorname{work}_{i, n, t}=\theta_{1} W P_{i, n, t}+ & \theta_{2} W N P_{i, n, t}+\theta_{3} N W N P_{i, n, t}+\theta_{4} N W P_{i, n, t} \\
& +b_{1} X_{i, t}+b_{2} X_{n, t}+\delta_{i}+\delta_{t}+E_{m s a, t}+e_{i, n, t}
\end{aligned}
$$

where the model error term $e_{i, n, t}$ captures the influence of any remaining unobserved timevarying, neighborhood-specific factors.

An important feature of (3.3) is that the peer and non-peer terms are individual level, neighborhood specific, time varying variables. Our primary threat to identification, therefore, are unobserved time varying neighborhood factors that may influence temporal variation in an individual's work status while also being correlated with temporal variation in proximity to working and non-working peers and non-peers. This could arise if proximity to nearby peers is endogenous, or because of unobserved local labor demand shocks, or because the work status of target and neighboring individuals simultaneously feedback on each other through (3.3). 
To clarify, suppose that peer effects do not exist in the sense that the true values for $\theta_{l}$, $\theta_{2}, \theta_{3}$, and $\theta_{4}$ are all zero. Suppose also that individuals choose their neighborhood to be close to peers and peers have similar unobserved tastes for work. Then this would bias upward the magnitude of the coefficients on the peer variables $\left(\theta_{1}\right.$ and $\left.\theta_{4}\right)$ and would cause us to overstate evidence of peer effects. Suppose instead that peer effects do exist as modelled in (3.2).

Simultaneous feedback between the work status of target individual and neighboring peers would bias upward the magnitude of the peer coefficients $\theta_{1}$ and $\theta_{4}$, also causing us to overstate evidence of peer effects. It is important, therefore, to control for possible endogenous temporal variation in both the peer and work status of neighbors within a given cluster.

Four features of our empirical design help to address these concerns. The first is the extreme proximity of neighbors in our data along with refined classifications of individuals into peer groups. The second is that in some models we rely on differencing to mitigate the influence of common unobserved factors. The third is that our preferred models proxy for the actual work status of adjacent peers and non-peers using MSA-level peer-specific employment rates. The fourth is that our data and the manner in which peer effects are specified allow us control for person fixed effects and rely on temporal variation for identification. We comment further on each of these strategies below.

\subsection{Identification}

\subsubsection{Neighbor proximity and classification of peers}

If individuals do not choose their residence based on anticipated changes in the peer status of prospective neighbors that will help to ensure that temporal variation in proximity to peers and non-peers is exogenous. The manner in which we define peers along with the special 
features of the AHS neighborhood cluster panel help to ensure that is the case. Considering the data first, recall that the housing clusters are constructed from groups of adjacent homes in MSAs across the U.S. While individuals may know the demographic attributes of their broader community when choosing a residence, it is less likely that they would know whether prospective neighbors on a given block or in the house next door were peers or non-peers before moving into their home. It is even less likely that individuals would know of upcoming changes in the peer status of prospective neighbors when choosing their residence. This is especially true in our more refined models for which neighbors are classified into up to thirty-six different types, only one of which is coded as a peer.

In the empirical work to follow, we experiment with thirteen different definitions of peers. In all cases except one, for each target individual $i$, peers are defined as neighbors that share common demographic traits with $i$ where the traits used for these purposes differ across peer definitions. The large number of peer definitions helps to establish robustness but also presents a challenge: how to choose a preferred classification scheme. On this we are guided by the following argument. At one extreme, suppose that neighborhood peer effects are present in the sense that the true model coefficients satisfy the inequalities in (3.2), but neighbors are randomly assigned as peers and non-peers. Then the peer and non-peer coefficients should be asymptotically similar which would imply an absence of peer effects. We begin with such a model as a base of reference. At the other extreme, suppose that we perfectly classify individuals as peers and non-peers. Given our strong priors that peers should have larger magnitude effects on an individual's work behavior than non-peers, accurate classification should maximize the difference between the peer and non-peer coefficients. 
Regardless of the peer classification being used, recall that our target sample is always restricted to individuals between ages 25 and 60 to ensure that the decision of whether or not to work is relevant. Our simplest peer definition then classifies all individuals between ages 25 and 60 as peers and those outside of this group as non-peers. The next level of classifications require that peers share one additional trait. The first such model treats individuals of the same gender as peers. The second model defines individuals with at least one similar age child at home as peers based on three different categories: no children at home under age 18, at least one child at home under age 6 , and at least one child at home between 6 and 18. Individuals with at least one child under age 6 and also at least one child between 6 and 18 are defined as peers for families with children in both age categories. The third model treats individuals of similar marital status as peers (married versus not married). The fourth model treats individuals as peers if they are of similar education status based on three categories, less than high school, high school or some college, and college degree or more. More refined definitions of peers interact two, three, and eventually all four of these classifications. Accordinarly, our most refined classification scheme divides individuals into thirty-six different types: gender (2 groups) by age of children at home (3 groups) by marital status ( 2 groups) by education (3 groups).

It is worth emphasizing that as peer definitions become more refined exposure to peers among adjacent neighbors declines sharply. For the broadest peer definition - all individuals between age 25 and 60 - summary measures in Table $1 \mathrm{~b}$ indicate that, on average, 8.5 neighbors are working peers, 0.95 neighbors are working non-peers, 2.7 neighbors are non-working nonpeers, and 2.3 neighbors are non-working peers. For the most refined peer definition - gender by marital status by education by age of children - the corresponding values are 1.2, 8.3, 4.7, and 0.1 , respectively. Especially for these more refined models it is unlikely that an individual would 
know when selecting a home if a prospective adjacent neighbor was a peer let alone whether the peer status of an adjacent neighbor was about to change.

Balancing that advantage, it should also be noted that excessively refined peer groupings would hurt our ability to identify peer effects. That is because overly refined peer goupings would mistakenly classify most peers as non-peers. Moreover, in the limit, overly refined peer classifications would code all neighbors as non-peers which would preclude estimation of the model. It is desirable, therefore, to consider a wide range of peer classifications as this helps to highlight possible tradeoffs.

\subsubsection{Differencing peer and non-peer effects}

As emphasized above, it is also important to address possible unobserved local labor demand shocks. For that reason, in some of our models we use a differencing strategy as this helps to difference away the influence of common time varying unobserved factors as with the arrival of a new nearby employer, for example. Specifically, we restrict $\theta_{1}=-\theta_{4}$ and $\theta_{2}=-\theta_{3}$ in expression (3.3). This implicitly assumes that working and non-working peers have similar magnitude but opposite signed effects on individual work behavior, and similarly for working and non-working non-peers. The regression model then becomes,

$$
\begin{aligned}
\operatorname{work}_{i, n, t}=\theta_{p}\left(\mathrm{WPi}_{, n, t}-N W P_{i, n, t}\right)+ & \theta_{n p}\left(\mathrm{WNP}_{\mathrm{i}, n, t}-N W N P_{i, n, t}\right) \\
& +b_{1} X_{i, t}+b_{2} X_{n, t}+\delta_{i}+\delta_{t}+E_{m s a, t}+e_{i, n, t}
\end{aligned}
$$

where $\theta_{p}$ and $\theta_{n p}$ are the influence of peers and non-peers on an individual's work behavior. Under the further assumption that peers have a larger impact on individual work behavior than non-peers, evidence that $\theta_{p}>\theta_{n p} \geq 0$ is consistent with the presence of peer effects. 
The model in (3.4) has the advantage of differencing away common unobserved local time varying factors that might bias evidence of peer effects. A disadvantage of (3.4) is that it oversimplifies the relationship between peers and non-peers relative to (3.3) causing us to lose our ability to shed light on underlying mechanisms (i.e. role model effects versus information spillovers). Differencing as in (3.4) also does not fully address the possible local time varying labor demand shocks. As noted above, such shocks have the potential to bias upward the magnitude of all of the peer and non-peer coefficients, and therefore, the magnitude of $\theta_{p}$ and $\theta_{n p}$ in (3.4). For these and other reasons we turn to our final and most robust modeling strategy.

\subsubsection{Proxying for neighbor work status}

In our most robust modeling strategy, we proxy for a neighbor's actual work status using MSA-level peer-specific employment rates in a manner described below. We favor this strategy for reasons outlined earlier. First, recall that adjacent peers may facilitate contact with a broader geographic community of peers that extends beyond the immediate housing cluster (as with school or religious groups, for example). It is plausible that access to that broader group could enhance word-of-mouth labor market networks and further contribute to role model effects. For that reason, the exmployment status of the broader geographic community is potentially relevant. Second, proxying for actual neighbor work status eliminates the possibility that time varying localized labor demand shocks might contaminate estimates of the peer effect variables in the manner discussed above. Third, proxying eliminates possible simultaneous feedback between the work status of adjacent neighbors and the work status of the target individual. Fourth, it controls for the tendency of an individual to work and for that reason, helps to reduce attenuation 
bias that would arise if an individual neighbor's work status in a given year is misreported or not indicative of that neighbor's typical behavior.

It is worth emphasizing that failing to allow for the second and third effects above could result in upward biased estimates of peer effects (see Section 3.2), while failing to address the first and fourth effects implies the opposite. For all of these reasons, we proxy for the actual work status of adjacent neighbors as follows. For a given peer definition, individual $i$ 's neighbors in year $t$ are divided into two groups, peers and non-peers. We proxy for the work behavior of neighboring peers using the year- $t$ employment rate among individuals in $i$ 's MSA that qualify as peers $\left(E_{i, P, m s a, t}\right)$. We proxy for the work behavior of neighboring non-peers in an analogous manner using the MSA-level employment rate for all non-peers combined $\left(E_{i, N P, m s a, t}\right)$. Applying this strategy, expression (3.4) becomes,

$$
\begin{aligned}
& \text { work }_{i, n, t}=\theta_{p}\left[\left(E_{i, P, m s a, t}\right) P_{i, n, t}-\left(1-E_{i, P, m s a, t}\right) P_{i, n, t}\right] \\
& \quad+\theta_{n p}\left[\left(E_{i, N P, m s a, t}\right) N P_{i, n, t}-\left(1-E_{i, N P, m s a, t}\right) N P_{i, n, t}\right] \\
& \quad+b_{1} X_{i, t}+b_{2} X_{n, t}+\delta_{i}+\delta_{t}+E_{m s a, t}+e_{i, n, t}
\end{aligned}
$$

where the terms $P_{i, n, t}$ and $N P_{i, n, t}$ are the number of peers and non-peers among adjacent neighbors and the overall MSA-level employment rate is retained as before. Observe also that the bracketed terms simplify to $2 \cdot E_{i, P, m s a, t} \cdot P_{i, n, t}-P_{i, n, t}$ and $2 \cdot E_{i, N P, m s a, t} \cdot N P_{i, n, t}-N P_{i, n, t}$, respectively. Thus, identification is only possible when MSA-level employment rates among peers and nonpeers differ from 0.5 which reflects that (3.5) relies on differences for identification.

Proxying for neighbor work behavior in the same fashion in expression (3.3) gives,

$$
\begin{aligned}
\text { work }_{i, n, t}=\theta_{1}\left(E_{i, P, m s a, t}\right) P_{i, n, t}+ & \theta_{2}\left(E_{i, N P, m s a, t}\right) N P_{i, n, t} \\
+ & \theta_{3}\left(1-E_{i, N P, m s a, t}\right) N P_{i, n, t}+\theta_{4}\left(1-E_{i, P, m s a, t}\right) P_{i, n, t} \\
& \quad+b_{1} X_{i, t}+b_{2} X_{n, t}+\delta_{i}+\delta_{t}+E_{m s a, t}+e_{i, n, t}
\end{aligned}
$$


Looking ahead, we favor the specification in (3.6) because it addresses the concerns highlighted above while providing evidence of peer effects as well as underlying mechanisms.

\subsubsection{Temporal variation in Work and Peer variables}

Identification of our models requires temporal variation in individual work status and also in the peer and non-peer variables. The lower panel of Table $1 \mathrm{~b}$ provides evidence on this point for the sample of individuals present in two or more consecutive surveys. Observe that the standard deviation of the change in the work variable between adjacent surveys is 0.36 and 0.46 for men and women, respectively. In addition, 16.7 percent of men in the estimating sample (379 individuals) experience a change in work status between surveys, while for women the corresponding value is 26.5 percent (690 individuals). This variation enables us to control for person fixed effects which is essential for identifiication. Observe also that even for the most refined peer classification (gender by marital status by education by children) the peer variables exhibit considerable temporal variation as seen in the standard deviations for the change in the peer variables in the lower panel of Table $1 \mathrm{~b}$. That variation arises from changes in the attributes of target and neighbor individuals in addition to in and out migration from the neighborhood cluster and is also essential for identification.

\section{Results}

\subsection{Baseline regressions - no peer effects}

Table 2 presents baseline regressions that include individual and neighborhood attributes but which omit the peer variables described earlier. Here and in all of the tables to follow the 
standard errors are clustered at the neighborhood level. Columns 1 and 2 report results for men and women without person fixed effects. Columns 3 and 4 include the fixed effects.

Results in Table 2 are consistent with priors. In the first two columns, for example, notice that the tendency to work increases with an individual's level of education but much less so for men than for women. The smaller magnitude effect of education for men is consistent with the view that the decision to work for men is more inelastic. As anticipated, the presence of children at home has a notably negative influence on a woman's tendency to work as does being married; these attributes do not deter male propensity to work.

Not surprisingly, most of the individual and neighborhood cluster attribute coefficients become small and insignificant upon including person fixed effects in the models in columns 3 and 4. This is because several of these attributes exhibit little change between surveys and are captured by the person fixed effects. ${ }^{11}$ The exception is that children and marital status continue to have sharp negative effects on female propensity to work as seen in column 4 of the table.

\subsection{Peer effects using actual neighbor work status}

We next present estimates of the models in expressions (3.3) and (3.4) which allow for peer effects based on the actual work status of nearby peers and non-peers. We begin with the restricted model in (3.4) for which the influence of working and non-working peers is assumed to be of equal magnitude but opposite sign, and similarly so for non-peers. Results from this model are presented in Tables $3 \mathrm{a}$ and $3 \mathrm{~b}$ for thirteen different peer definitions. In both tables, estimates for men are in Panel A while estimates for women are in Panel B.

\footnotetext{
${ }^{11}$ It is for this reason that variables such as individual race and age are not included in the model. Race is time invariant while in the case of age, all individuals advance four years between surveys which is fully captured by the person fixed effects.
} 
In Table 3a, the first column in both panels is based on a random assignment of neighbors as peers and non-peers as a base of reference. As described earlier, random assignment should not yield evidence of peer effects. Notice that in both panels, the coefficients on non-peers in column 1 are larger than the coefficients on peers, opposite of what should occur in the presence of peer effects. The model in column 2 provides an alternate base of reference in that it treats all neighbors between age 25 and 60 as peers while all other neighbors are non-peers. For men the coefficients on peers and non-peers are nearly identical and not significant, once again inconsistent with peer effects. For women, the peer coefficient is positive and significant while the non-peer coefficient is close to zero, indicating that peer effects could be present.

The remaining models in Table $3 \mathrm{a}$ enrich the definition of a peer. Column 3 further requires that a peer must be of the same gender as the target individual in addition to being between age 25 and 60. Column 4 substitutes marital status (married, not married) for gender when defining peers. Column 5 uses education which, as noted earlier, is broken into three categories: less than high school, high school or some college, and college degree or more. Column 6 uses age of children in the home based on whether there are no children present, at least one child under age 6 , and at least one child age 6 to 18 .

Several patterns are noteworthy in these later models. First, for both men and women, proximity to peers based on gender (column 3) is significantly and positively associated with an individual's tendency to work. Second, proximity to peers based on education (column 5) or the presence of similar age children (column 6) is significantly and positively associated with the tendency for women to work but not for men. Third, recall that we anticipate that $\theta_{p}>\theta_{n p}$ in expression (3.4) and that accurate classification of neighbors as peers and non-peers should maximize the spread between $\theta_{p}$ and $\theta_{n p}$. Accordingly, 1-tailed tests of the difference between 
the peer and non-peer coefficients are presented in the middle of each panel for each of the models. For men, gender appears to be the most credible way of classifying adjacent neighbors as peers while for women, age, gender and children stand out. For women, these patterns will be recurring themes as we move to more robust specifications in the tables to follow.

Table $3 \mathrm{~b}$ further enriches the definition of peers while maintaining the same general specification in expression (3.4). In all cases, peers must be between age 25 and 60 as before. In addition, columns 1-3 interact gender with marital status, education, and age of children, respectively. Column 4 interacts gender, marital status and education. Column 5 inteacts gender, marital status, and age of children. Column 6 interacts gender, education, and age of children. Column 7 interacts gender, marital status, education, and age of children, which yields thirty-six different peer classifications as noted earlier.

The results in Panel A for men suggest that gender-education (column 2) is the most compelling manner in which to classify individuals as peers. For that specification, notice that the coefficient on peers indicates that adding 1 additional peer to the adjacent neighbors changes an individual's tendency to work by 1.17 percentage points while adding a non-peer has a much smaller effect of just 0.27 percentage points. There is intuitive appeal that men might be more likely to view other men of similar education as their primary peers. Nevertheless, it is also concerning that the peer effect coefficient is so large given our stong prior that for men the decision to work as defined here in this paper is highly inelastic. Moreover, the coefficient for men in column 2 is similar in magnitude to the corresponding coefficient for women in Panel B. This raises concerns about whether unobserved time varying labor demand shocks might be driving the peer effect coefficient for men. We will return to this point shortly. First, however, consider the patterns for women. 
In Panel B of Table $3 \mathrm{~b}$ (for women), the specifications in columns 3, 6 and 7 appear to maximize the difference between the coefficients for peers and non-peers. This suggests that gender, child status, and education together are most effective in defining how women view potential peers. Although the further influence of marital status in column 7 does increase the difference between $\theta_{p}$ and $\theta_{n p}$ slightly relative to column 6 , it is worth noting that in column 4 the difference between $\theta_{p}$ and $\theta_{n p}$ is notably smaller and not significant when peers are defined based on gender, education and marital status. From these patterns we conclude that gender, child status, and education are important in defining peers for women but not marital status.

Focusing on column 6, the estimates imply that adding one additional peer to a woman's housing cluster will affect her work status by 1.4 percentage points. Adding one additional nonpeer to the women's cluster affects her work status by only 0.15 percentage points. It is also worth noting that for the column 6 classification of peers (gender by child status by education), only 12 percent of a women's adjacent neighbors are peers as indicated in the summary measures at the bottom of Table $3 b$.

In Table 4 we present estimates based on the model in expression (3.3). This model continues to use the actual work behavior of neighbors to classify their work status but relaxes the coefficient restrictions imposed on (3.4). To conserve space, estimates are reported for just seven of the peer classifications and are ordered across columns as follows: (1) gender, (2) child status, (3) gender-education, (4) gender-child, (5) gender-education-marital status, (6) gendereducation-child, and (7) gender-education-child-marital status. As before, estimates for men are in Panel A and for women in Panel B.

As a broad characterization, estimates for men yield limited evidence of peer effects. None of the models, for example, yield positive significant coefficients on nearby working peers 
and in some instances the coefficient has the wrong sign. On the other hand, several of the models yield sharp negative coefficients on non-working non-peers and peers. The mix of estimates here raises concerns about the possible influence of localized time-varying labor demand shocks as might occur with the departure of a nearby employer, for example.

For women (Panel B), the point estimates are closer to our priors but often not significant. All of the working peer variables (WP) have positive coefficients but only the estimate in column 6 (gender-education-child) is close to significant by conventional measures with a t-ratio of 1.5. All of the non-working peer coefficients are negative and at least marginally significant in columns $2,4,5$, and 7 with t-ratios above 1.5 . These estimates roughly conform to our priors. Nevertheless, when considered in conjunction with the other patterns in Tables $3 \mathrm{a}, 3 \mathrm{~b}$, and 4 , we remain concerned that the specifications thus far do not adequately allow for the combined effects of unobserved time varying labor demand shocks, simultaneous feedback between target individuals and peers, measurement error, and a possible role for peers and non-peers beyond the immediate neighborhood cluster.

\subsection{Peer effects proxying with MSA-level employment rates}

We turn now to our most robust models which proxy for actual neighbor work status with peer-specific MSA-level employment rates as described earlier. As before, we begin with the restricted model, expression (3.5) in this case, and then follow with the unrestricted model based on expression (3.6). Estimates are presented in Tables $5 \mathrm{a}$ and $5 \mathrm{~b}$ for the two specifications, respectively, for the same seven peer definitions as in Table 4.

Consider Panel A of Tables 5a and 5b first, for men. It is evident that any evidence of peer effects has disappeared. In both tables, the coefficients are mostly small, always far from 
significant, and often of the wrong sign. This is evident in the negative coefficients on non-peers in the second row of Table 5a (WNP - NWNP) and the negative coefficients on working peers (WP) in the first row in Table 5b. The prevelance of small, insignificant coefficients is what should occur given the highly inelastic tendency for men to secure positive earnings over the course of a twelve month period.

A sharply different pattern is evident for women. Consider first Table 5a, which presents estimates based on the restricted specification. There is compelling evidence of peer effects based on the peer definitions in columns 3 and 6, gender-child and gender-education-child, respectively, echoing results from Table 3 b. In column 6 , for example, the difference in the peer and non-peer coefficients is 2.66 percentage points and significant. Based on this model, adding one additional peer to a woman's neighborhood cluster affects her propensity to work by 3.36 percentage points. Adding one additional non-peer affects work propensity by just 0.69 percentage points. Similar values are present in column 4 of Table $5 \mathrm{a}$ for the gender-child peer definition. Other peer classifications yield notably less evidence of peer effects.

Consider next Table $5 \mathrm{~b}$ which presents estimates based on our more general specification in expression (3.6). Once again gender-child (column 4) and gender-child-education (column 6) appear to be the most compelling definitions of peers. For both of those specifications, the estimates support the underlying theory described in expression (3.2) that $\theta_{1}>\theta_{2} \geq 0 \geq \theta_{3}>\theta_{4}$. The negative and significant coefficient on non-working peers in these columns is especially informative. As argued earlier, while such individuals may not be a valuable source of information on job market opportunities, it seems unlikely that proximity to such individuals would impede access to information on potential jobs. On the other hand, the presence of such individuals would contribute to role model effects that would discourage a woman from 
choosing to work. For these reasons, we believe that the patterns in columns 4 and 6 provide unambiguous evidence that role model effects of nearby peers influence a woman's decision to work. In contrast, the positive coefficients on working peers in columns 4 and 6 could reflect role model effects and/or information spillovers associated with word-of-mouth job market networks as emphasized in Hellerstein et al (2014) and Bayer et al (2008).

\subsection{Robustness}

\subsubsection{Extensions}

Table 6a presents estimates from a series of extensions designed to further explore the robustness of our estimates. In all cases, actual work status is proxied with MSA-level peerspecific employment rates as above. To avoid proliferation of tables, only estimates for the gender-child and gender-child-education peer classifications are presented. Summary statistics for key variables in the first two extensions are provided in the appendix, Table A-1.

Columns 1-4 present estimates for single and married women separately. Notice that the point estimates for single and married women are similar both to each other and also to estimates for all women (single plus married) in the corresponding models in Table 5b. The estimates also have larger standard errors and are less significant than the corresponding estimates in Table $5 \mathrm{~b}$, but we believe that is primarily a result of having split the sample in half which reduces power. On balance, the estimates in columns 1-4 suggest that the peer effects documented for women above apply to both single and married women.

Columns 5-8 present estimates for men and women (married plus single combined) using a modified dependent variable for which work is equal to 1 if the individual earned more than $\$ 5,000$ in the previous year (in year $2013 \$$ ) and 0 otherwise. Here too estimates are similar to 
the corresponding models in Table 5b although slightly smaller in magnitude and significance for women. This suggests that our primary estimates from Table $5 \mathrm{~b}$ are not sensitive to modest reclassifications of the dependent variable. ${ }^{12}$

In columns 9 and 10 we revisit the restricted difference-models from Table 5a and add controls for counts of neighborhood peers and non-peers and their corresponding MSA-level employment rates. In columns 11 and 12 we repeat this exercise for the unrestricted models in Table $5 \mathrm{~b}$ but add controls for just the MSA-level peer-specific employment rates as further addition of counts of neighboring peers and non-peers would result in perfect colinearity. The important result in columns $9-12$ is that the coefficients on the main effects are mostly not signicant and their inclusion has little effect on the peer interaction terms.

\subsubsection{Residual diagnostics and exogeneity}

As emphasized throughout the paper, our ability to identify peer effects requires that temporal variation in the peer and non-peer variables is exogenous conditional on the various model controls. In other words, there should be no unobservable factors driving both neighborhood formation and work decisions. We provide here a set of residual-based diagnostic tests that help to reveal whether our models may violate such exogeneity conditions. ${ }^{13}$ The intuition behind these tests is to evaluate whether differences in unobserved factors that drive temporal variation in the work behavior of two individuals helps to explain whether those individuals live in the same neighborhood cluster. Indeed, homophily behavior in neighborhood formation would imply that the closer two individuals are in terms of observable (and

\footnotetext{
${ }^{12}$ As noted earlier, these patterns change as the income threshold is increased up to $\$ 50,000$ which reflects the complicated mixing of the decision to work, hours worked, and individual wage.

${ }^{13}$ Patacchini and Venanzoni (2014) use a similar strategy to demonstrate the importance of network fixed effects in identifying peer effects in the demand for housing quality. See also Goldsmith-Pinkham and Imbens (2013) for a related test procedure in a different context.
} 
unobservable) characteristics, the higher is the probability that they reside in the same neighborhood. Evidence of correlation would be suggestive that unobserved individual-specific factors may affect neighborhood choice as well as the decision to work, which could point to a potential violation of exogeneity.

To implement this exercise, all unique pairs of individuals used in a given work regression are first determined. Each pair is then classified as neighbors if the two individuals live in the same neighborhood cluster in the same survey year. This is coded by setting Neighbor $_{i, j}$ to 1 for neighbors and 0 otherwise. For each pair we also calculate the absolute value of the difference in the observed attributes of the two individuals, denoted as Dif__ $X_{i, j}$, and the absolute value of the difference in their residuals from the work regression which we refer to as Dif $_{-} e_{i, j}$. Having formed these variables, we estimate a linear probability model with Neighbor $_{i, j}$ as the dependent variable and Dif_X $X_{i, j}$ and Dif $\__{i, j}$ as controls,

$$
\text { Neighbor }_{i, j}=a_{0}+a_{1} \text { Dif__ }_{i, j}+a_{2} \text { Dif_- }_{i, j}+\varepsilon_{i, j}
$$

where the coefficient of interest is $a_{2}$.

Estimates of expression (4.1) are presented in the appendix Tables A-2a and A-2b for each model in Tables $5 \mathrm{a}$ and $5 \mathrm{~b}$, respectively. Coefficients on Dif $\_e_{i, j}$ are also presented in Table $6 \mathrm{~b}$ where they are normalized by dividing by the unconditional mean probability that two individuals live in the same neighborhood cluster (which equals 0.16 percent for men and 0.15 percent for women). The normalized coefficients in Table $6 \mathrm{~b}$ should be interpreted as indicating the impact of a 1.0 unit difference in the work regression residuals for two individuals, equivalent to a 100 percentage point difference in their probability of working. It should also be noted that because there are several million individual-pair observations in a given regression, the power to detect small departures from zero is quite high. 
Focusing on Table $6 \mathrm{~b}$, notice that for men, regardless of the peer definition being used, a 1-unit increase in the difference in residuals is associated with a roughly 13 percent decrease in the probability that two individuals live in the same neighborhood cluster relative to the unconditional mean probability. This effect is small in economic terms but statistically significant as indicated by summary measures in the appendix tables (Tables A-2a and A-2b). For women the test statistics are even smaller and not significant. The normalized coefficients in Table $6 \mathrm{~b}$ suggest that a 1 -unit increase in the difference in the residuals is associated with a roughly 3.5 percent decrease in the probability that two individuals live in the same cluster relative to the unconditional mean. This inability to document notable correlation between differences in unobserved individual characteristics and neighborhood formation provides further support for the view that temporal variation in the peer and non-peer variables is exogenous conditional on person fixed effects and other model controls.

\section{Conclusions}

A host of policy and household decisions are based on belief that neighborhood peer effects are important. Nevertheless, peer effects have been notoriously difficult to identify as have the mechanisms by which they are transmitted. This paper makes progress on both fronts by developing a new modeling structure that emphasizes identification of peers as opposed to peer effects per se, and by also drawing on geographically concentrated panel data. Together, these features of our research design enable us to address difficult identification issues that have plagued this literature. Our research design could also be applied to other settings in which peer effects arise from possible combinations of role model effects and information spillovers. Examples include classroom performance of students, juvenile delinquency, the adoption of new 
technologies, physicians' drug prescriptions, vaccination patterns and portfolio choices. In many of these sorts of settings the distinction between the effect of culture and information sharing can also be important when forming public policy.

Our estimates suggest that for women, peer effects influence labor supply in part because women appear to emulate the work behavior of nearby women with similar age children. In our most robust specifications adding one additional working peer to a women's adjacent neighbors increases her tendency to work by 4.5 percentage points. Adding a non-working peer reduces her tendency to work by 9 percentage points. Adding non-peers to a women's adjacent neighbors has little influence on her decision to work. Placebo tests based on men yield limited evidence of peer effects, consistent with the decision to work being highly inelastic.

Our finding that peer definitions for women depend on the presence and age of children is consistent with work by Graves (2013), Compton and Pollak (2014) and Black et al (2014). Graves (2013) shows that school calendars affect female labor supply. Compton and Pollack (2014) show that women are more likely to work if they live near to the children's grandparents. Black et al (2014) show that women are more likely to work if they live in less congested metropolitan areas with shorter commute times. All three studies suggest the need for women to have viable child care if they are to work, either by relying on others (e.g. grandparents or schools) or because they can readily drive from work to home or a child's school if needed.

Our paper also reinforces an extensive literature on the importance of cultural norms as drivers of economic decisions and for the persistence of beliefs, norms, and socio-economic status across generations (e.g. Alesina and Giuliano (2010), Bisin and Verdier (2011)). While some studies argue that stagnation in womens' labor force participation in the United States can be attributed at least in part to limited adoption of "family-friendly" policies (e.g. Blau and Kahn 
(2013)) our study confirms the importance of neighborhood-based cultural factors in shaping female labor market participation. 


\section{References}

Alesina, Alberto and Paola Giuliano (2010). "The Power of the Family," Journal of Economic Growth, 15 (2): 93P125.

Alesina, Alberto, Giuliano, Paola and Nathan Nunn (2013). On the Origins of Gender Roles: Women and the Plough. Quarterly Journal of Economics, 128(2): 469-530.

Asphjell, Magne, Lena Hensvik, and Peter Nilsson (2013). "Business, Buddies, and Babies: Fertility and Social Interactions at Work." Uppsala University, Center for Labor Studies, Working Paper 2013(8).

Bayer, Patrick, Stephen Ross, and Giorgio Topa (2008). "Place of Work and Place of Residence: Informal Hiring Networks and Labor Market Outcomes." Journal of Political Economy 116(6): 1150-1196.

Beaman, Lori (2012). "Social Networks and the Dynamics of Labour Market Outcomes: Evidence from Refugees Resettled in the U.S.” Review of Economic Studies 79(1): 128-161.

Bertrand, Marianne (2010). "New Perspectives on Gender," in (O. Ashenfelter and D. Card eds), Handbook of Labor Ecomics volume 4B, pp. 1545-1592.

Black, Dan, Natalia Koleznikova, and Lowell Taylor (2014). "Why do so few women work in New York (and so many in Minneapolis)? Labor supply of married women across US cities." Journal of Urban Economics, 79:59-71.

Bisin, A. and T. Verdier (2011). "The economics of cultural transmission and socialization," in J. Benhabib, A. Bisin, and M.O. Jackson (Eds.), Handbook of Social Economics, Amsterdam: Elsevier Science, pp. 339-416.

Calvo-Armengol, Antoni, and Matthew Jackson (2004). "The Effects of Social Networks on Employment and Inequality." American Economic Review 94(3):426-454

Cappellari, Lorenzo, and Konstantinos Tatsiramos (2010). "Friends' Networks and Job Finding Rates.” CESifo Working Paper Series 3243.

Cingano, Federico, and Alfonso Rosolia (2012). "People I Know: Job Search and Social Networks.” Journal of Labor Economics 30(2): 291-332.

Compton, Janice, and Robert Pollak (2014). "Family Proximity, Childcare, and Women's Labor Force Attachment." Journal of Urban Economics, 79:72-90.

Damm, Anna P. (2014). "Neighborhood Quality and Labor Market Outcomes: Evidence from Quasi-Random Neighborhood Assignment of Immigrants.” Journal of Urban Economics, 79:139-166. 
Damm, Anna, P. (2009). "Ethnic Enclaves and Immigrant Labor Market Outcomes: QuasiExperimental Evidence,” Journal of Labor Economics, 27(2): 281-314.

Gibbons, Steve, Henry Overman, and Eleonora Patacchini (forthcoming). "Spatial Methods," in Handbook of Regional and Urban Economics, Gilles Duranton, Vernon Henderson, and William Strange (Eds.), Amsterdam: Elsevier Science, Volume 5.

Graves, Jenifer (2013), "School Calendars, Child Care Availability and Maternal Employment," Journal of Urban Economics, 78: 57-70.

Goldsmith-Pinkham, Paul, and Guido Imbens (2013). "Social Networks and the Identification of Peer Effects.” Journal of Business \& Economic Statistics, 31(3): 253-264.

Granovetter, Mark (2005). "The Impact of Social Structure on Economic Outcomes.” Journal of Economic Perspectives 19(1):33-50.

Fernández, R. (2011). "Does culture matter?” in J. Benhabib, A. Bisin, and M.O. Jackson (Eds.), Handbook of Social Economics, Amsterdam: Elsevier Science, pp. 481-510.

Fernández, R., Fogli, A. and C. Olivetti (2004), "Mothers and sons: Preference formation and female labor force dynamics," Quarterly Journal of Economics, 119, 1249-1299.

Fogli, A. and L. Veldkamp (2011), "Nature or nurture? Learning and the geography of female labor force participation," Econometrica, 79, 1103-1138.

Hellerstein, Judith, Mark Kutzbach, and David Neumark (2014). "Do Labor Market Networks have an Important Spatial Dimension?" Journal of Urban Economics, 79:39-58.

Hellerstein, Judith, Melissa McInerney, and David Neumark (2011). "Neighbors and Coworkers: The Importance of Residential Labor Market Networks." Journal of Labor Economics 29(4): $659-695$.

Ioannides Y.M. and J.E. Zabel (2003). "Neighbourhood effects and housing demand," Journal of Applied Econometrics, 18(5), 563-584.

Ioannides, Yannis, and Linda Datcher Loury (2004). "Job Information Networks, Neighborhood Effects, and Inequality." Journal of Economic Literature 42(4): 1056-1093.

Ioannides, Y. and J. Zabel (2008). "Interactions, neighbourhood selection and housing demand," Journal of Urban Economics, 63: 229-252.

Ioannides, Yannis (2012). From Neighborhoods to Nations: The Economics of Social Interactions, Princeton University Press.

Manski, Charles (1993). "Identification of Endogenous Social Effects: The Reflection Problem." Review of Economic Studies 60(3): 531-542. 
Manski, Charles (2000). "Economic Analysis of Social Interactions." Journal of Economic Perspectives 14(3): 115-136.

Olivetti, Claudia, Eleonora Patacchini, and Yves Zenou (2013), "Mothers, Friends, and Gender Identity," NBER Working Paper 19610.

Patacchini, Eleonora and Giuseppe Venanzoni (2014). "Peer Effects in the Demand for Housing Quality“, Journal of Urban Economics 83: 6-17.

Topa, Giorgio (2001). "Social Interactions, Local Spillovers and Unemployment." Review of Economic Studies 68(2): 261-295.

Topa, Giorgio and Yannis Ioannides (forthcoming). "Neighbourhood Versus Network Effects," in Handbook of Regional and Urban Economics, Gilles Duranton, Vernon Henderson, and William Strange (Eds.), Amsterdam: Elsevier Science, Volume 5.

Weinberg, Bruce, Patricia Reagan, and Jeffrey Yankow (2004). "Do Neighborhoods Affect Hours Worked? Evidence from Longitudinal Data." Journal of Labor Economics 22(4): 891924. 
Table 1a: Summary Statistics For Individual and Neighborhood Attributes

\begin{tabular}{|c|c|c|c|c|c|c|c|c|}
\hline \multirow[b]{3}{*}{ Person-Specific Attributes } & \multicolumn{4}{|c|}{$\begin{array}{c}\text { Adults Age } 25 \text { to } 60 \\
\text { Present in at least } 1 \text { Survey }\end{array}$} & \multicolumn{4}{|c|}{$\begin{array}{l}\text { Adults Age } 25 \text { to } 60 \\
\text { Present in at least } 2 \\
\text { Consecutive Surveys }\end{array}$} \\
\hline & \multicolumn{2}{|c|}{ Men } & \multicolumn{2}{|c|}{ Women } & \multicolumn{2}{|c|}{ Men } & \multicolumn{2}{|c|}{ Women } \\
\hline & Mean & Std.Dev & Mean & Std.Dev & Mean & Std.Dev & Mean & Std.Dev \\
\hline \multicolumn{9}{|l|}{ Education } \\
\hline - $\quad$ Less than high school & 0.137 & 0.343 & 0.155 & 0.362 & 0.120 & 0.325 & 0.134 & 0.340 \\
\hline - $\quad$ HS and some college & 0.527 & 0.499 & 0.593 & 0.491 & 0.528 & 0.499 & 0.614 & 0.487 \\
\hline - $\quad$ BA degree or more & 0.337 & 0.473 & 0.252 & 0.434 & 0.351 & 0.477 & 0.253 & 0.435 \\
\hline Child in $\mathrm{HH}$ & 0.518 & 0.500 & 0.556 & 0.497 & 0.555 & 0.497 & 0.559 & 0.497 \\
\hline Married & 0.762 & 0.426 & 0.693 & 0.461 & 0.819 & 0.385 & 0.755 & 0.430 \\
\hline Age & 41.2 & 9.8 & 41.0 & 9.9 & 43.4 & 8.8 & 43.1 & 9.0 \\
\hline \multicolumn{9}{|c|}{$\begin{array}{l}\text { Average Attributes of } \\
\text { Neighboring Adults Aged } 25 \text { to } 60\end{array}$} \\
\hline Not Including Target Person ${ }^{a}$ & Mean & Std.Dev & Mean & Std.Dev & Mean & Std.Dev & Mean & Std.Dev \\
\hline \multicolumn{9}{|l|}{ Education } \\
\hline - $\quad$ Less than high school & 0.141 & 0.209 & 0.151 & 0.216 & 0.124 & 0.196 & 0.138 & 0.205 \\
\hline - $\quad$ HS and some college & 0.562 & 0.250 & 0.562 & 0.246 & 0.567 & 0.248 & 0.567 & 0.242 \\
\hline - $\quad$ BA degree or more & 0.298 & 0.268 & 0.287 & 0.266 & 0.310 & 0.266 & 0.296 & 0.263 \\
\hline Child in $\mathrm{HH}$ & 0.510 & 0.277 & 0.527 & 0.276 & 0.534 & 0.260 & 0.544 & 0.260 \\
\hline Married & 0.710 & 0.275 & 0.704 & 0.274 & 0.765 & 0.241 & 0.750 & 0.248 \\
\hline Age & 41.1 & 5.3 & 41.2 & 5.4 & 41.9 & 5.1 & 42.0 & 5.2 \\
\hline Aged between 25 and $60^{\mathrm{b}}$ & 0.725 & 0.187 & 0.722 & 0.189 & 0.725 & 0.184 & 0.722 & 0.184 \\
\hline Number of neighborhoods & \multicolumn{2}{|c|}{725} & \multicolumn{2}{|c|}{728} & \multicolumn{2}{|c|}{630} & \multicolumn{2}{|c|}{653} \\
\hline Number of neigh*year clusters & \multicolumn{2}{|c|}{1,988} & \multicolumn{2}{|c|}{2,019} & \multicolumn{2}{|c|}{1,696} & \multicolumn{2}{|c|}{1,792} \\
\hline Number of adults & \multicolumn{2}{|c|}{6,470} & \multicolumn{2}{|c|}{7,273} & \multicolumn{2}{|c|}{2,272} & \multicolumn{2}{|c|}{2,608} \\
\hline Number of observations & \multicolumn{2}{|c|}{9,607} & \multicolumn{2}{|c|}{10,917} & \multicolumn{2}{|c|}{5,409} & \multicolumn{2}{|c|}{6,252} \\
\hline
\end{tabular}


Table 1b: Summary Statistics For Employment and Peer Variables

(Sample include only individuals present in two or more surveys who are age 25-60 in both surveys)

\begin{tabular}{|c|c|c|c|c|}
\hline \multirow[b]{2}{*}{ Level based on pooled surveys } & \multicolumn{2}{|c|}{ Men } & \multicolumn{2}{|c|}{ Women } \\
\hline & Mean & Std.Dev & Mean & Std.Dev \\
\hline Work Last Year ${ }^{\mathrm{a}}$ & 0.891 & 0.311 & 0.697 & 0.460 \\
\hline \multicolumn{5}{|l|}{ Peer Definition: Aged 25 to 60} \\
\hline - Working Peers (WP) & 8.671 & 3.421 & 8.438 & 3.455 \\
\hline - Working Non-Peers (WNP) & 0.946 & 1.427 & 0.941 & 1.400 \\
\hline - Non-Working Non-Peers (NWNP) & 2.677 & 2.295 & 2.674 & 2.317 \\
\hline - Non-Working Peers (WNP) & 2.308 & 1.881 & 2.320 & 1.905 \\
\hline \multicolumn{5}{|c|}{ Peer Definition: Gender*Mar*Educ*Child Status } \\
\hline - Working Peers (WP) & 1.199 & 1.373 & 0.861 & 1.041 \\
\hline - Working Non-Peers (WNP) & 8.335 & 3.169 & 8.454 & 3.224 \\
\hline - Non-Working Non-Peers (NWNP) & 4.692 & 2.512 & 4.349 & 2.497 \\
\hline - Non-Working Peers (WNP) & 0.134 & 0.406 & 0.431 & 0.796 \\
\hline Change between adjacent surveys & Mean & Std.Dev & Mean & Std.Dev \\
\hline Work Last Year ${ }^{\mathrm{a}}$ & -0.024 & 0.364 & 0.002 & 0.456 \\
\hline Percent that change work status & $16.7 \%$ & - & $26.5 \%$ & - \\
\hline Number that change work status & 379 & - & 690 & - \\
\hline \multicolumn{5}{|l|}{ Peer Definition: Aged 25 to 60} \\
\hline - Working Peers (WP) & -0.249 & 2.549 & -0.282 & 2.512 \\
\hline - Working Non-Peers (WNP) & 0.018 & 1.716 & -0.006 & 1.674 \\
\hline - Non-Working Non-Peers (NWNP) & 0.190 & 1.809 & 0.168 & 1.834 \\
\hline - Non-Working Peers (WNP) & -0.238 & 2.014 & -0.231 & 1.998 \\
\hline \multicolumn{5}{|c|}{ Peer Definition: Gender*Mar*Educ*Child Status } \\
\hline - Working Peers (WP) & -0.141 & 1.365 & -0.069 & 1.099 \\
\hline - Working Non-Peers (WNP) & -0.108 & 2.711 & -0.226 & 2.557 \\
\hline - Non-Working Non-Peers (NWNP) & -0.092 & 2.296 & -0.045 & 2.326 \\
\hline - Non-Working Peers (WNP) & -0.003 & 0.497 & -0.094 & 0.844 \\
\hline
\end{tabular}

${ }^{a}$ An individual is considered employed if he or she had positive wage earnings in the previous year. 
Table 2: Employment Regressions - No Peer Effects ${ }^{\mathrm{a}}$

(standard errors clustered at the neighborhood level in parentheses)

\begin{tabular}{|c|c|c|c|c|}
\hline & $\begin{array}{c}\text { Men } \\
(1)\end{array}$ & $\begin{array}{c}\text { Women } \\
(2)\end{array}$ & $\begin{array}{c}\text { Men } \\
(3)\end{array}$ & $\begin{array}{c}\text { Women } \\
(4)\end{array}$ \\
\hline \multicolumn{5}{|l|}{ Individual Characteristics } \\
\hline High school degree or some college & $\begin{array}{c}0.0735^{* * *} * \\
(0.0199)\end{array}$ & $\begin{array}{c}0.173 * * * \\
(0.0263)\end{array}$ & $\begin{array}{c}0.00653 \\
(0.0723)\end{array}$ & $\begin{array}{l}-0.0880 \\
(0.0905)\end{array}$ \\
\hline College degree or more & $\begin{array}{c}0.0873 * * * \\
(0.0212)\end{array}$ & $\begin{array}{c}0.291 * * * \\
(0.0283)\end{array}$ & $\begin{array}{c}-0.0136 \\
(0.0923)\end{array}$ & $\begin{array}{c}0.0190 \\
(0.101)\end{array}$ \\
\hline At least one child $<$ age 18 present at home & $\begin{array}{c}0.0259 * * * \\
(0.00990)\end{array}$ & $\begin{array}{c}-0.0325^{* *} \\
(0.0144)\end{array}$ & $\begin{array}{c}-0.0109 \\
(0.0199)\end{array}$ & $\begin{array}{c}-0.0450 * \\
(0.0255)\end{array}$ \\
\hline Married & $\begin{array}{l}0.00248 \\
(0.0136)\end{array}$ & $\begin{array}{c}-0.113 * * * \\
(0.0178)\end{array}$ & $\begin{array}{c}0.0433 \\
(0.0314)\end{array}$ & $\begin{array}{c}-0.121 * * * \\
(0.0397)\end{array}$ \\
\hline \multicolumn{5}{|l|}{ Neighbor and MSA Characteristics ${ }^{b}$} \\
\hline Percent High school degree or some college & $\begin{array}{c}0.0107 \\
(0.0338)\end{array}$ & $\begin{array}{c}0.153 * * * \\
(0.0528)\end{array}$ & $\begin{array}{c}-0.0910 \\
(0.0766)\end{array}$ & $\begin{array}{c}0.0374 \\
(0.0748)\end{array}$ \\
\hline Percent College degree or more & $\begin{array}{c}0.0198 \\
(0.0330)\end{array}$ & $\begin{array}{l}0.0960 * \\
(0.0520)\end{array}$ & $\begin{array}{c}-0.0964 \\
(0.0818)\end{array}$ & $\begin{array}{l}-0.0124 \\
(0.0952)\end{array}$ \\
\hline Percent age 25 to 60 & $\begin{array}{c}0.0317 \\
(0.0306)\end{array}$ & $\begin{array}{c}-0.0578 \\
(0.0428)\end{array}$ & $\begin{array}{c}0.0267 \\
(0.0618)\end{array}$ & $\begin{array}{c}-0.0148 \\
(0.0723)\end{array}$ \\
\hline Percent with at least one child $<18$ at home & $\begin{array}{c}0.0346 \\
(0.0218)\end{array}$ & $\begin{array}{c}-0.0139 \\
(0.0317)\end{array}$ & $\begin{array}{c}0.0345 \\
(0.0410)\end{array}$ & $\begin{array}{c}0.0372 \\
(0.0423)\end{array}$ \\
\hline Percent Married & $\begin{array}{c}-0.00474 \\
(0.0293)\end{array}$ & $\begin{array}{c}0.0564 \\
(0.0384)\end{array}$ & $\begin{array}{c}-0.0596 \\
(0.0531)\end{array}$ & $\begin{array}{l}0.00868 \\
(0.0513)\end{array}$ \\
\hline MSA employment rate ${ }^{c}$ & $\begin{array}{c}0.197 \\
(0.1600)\end{array}$ & $\begin{array}{c}0.0442 \\
(0.2150)\end{array}$ & $\begin{array}{c}0.347 \\
(0.2890)\end{array}$ & $\begin{array}{c}0.371 \\
(0.3010)\end{array}$ \\
\hline Person Fixed Effects & - & - & 2,272 & 2,608 \\
\hline Year Fixed Effects & Yes & Yes & Yes & Yes \\
\hline Observations & 5,409 & 6,252 & 5,409 & 6,252 \\
\hline R-squared & 0.013 & 0.058 & 0.587 & 0.700 \\
\hline \multicolumn{5}{|c|}{$\begin{array}{l}{ }^{a} \text { Sample includes individuals age } 25-60 \text {. Individuals are defined as working if they had positive earned income in the } \\
\text { previous year. All models are estimated using the American Housing Survey neighborhood cluster file panel (1985- } \\
\text { 1993). One * indicates significant at the } 10 \text { percent level; two stars at the } 5 \text { percent level; and three stars at the } 1 \\
\text { percent level. } \\
\text { b Calculated based on all working age ( } 25 \text { to } 60 \text { years old) neighbors, except for "Percent age } 25 \text { to } 60 \text { " which is } \\
\text { calculated based on all neighbors age } 18 \text { and over. } \\
{ }^{c} \text { Calculated using the Current Population Survey (CPS) which was obtained from www.ipums.org. }\end{array}$} \\
\hline
\end{tabular}


Table 3a: Restricted Model With Actual Neighbor Work Status ${ }^{\mathrm{a}}$ (standard errors clustered at the neighborhood level in parentheses)

\begin{tabular}{|c|c|c|c|c|c|c|}
\hline \multicolumn{7}{|c|}{ PANEL A - MEN } \\
\hline \multicolumn{7}{|c|}{ All Ages } \\
\hline Peer Group Definition & Random & $25-60$ & Gender & Married & Education & Child \\
\hline & (1) & (2) & (3) & (4) & $(5)$ & $(6)$ \\
\hline $\begin{array}{l}\text { N working peer - } \\
\text { N non-wrk peer (WP - NWP) }\end{array}$ & $\begin{array}{c}0.00257 \\
(0.00255)\end{array}$ & $\begin{array}{c}0.00403 \\
(0.00263)\end{array}$ & $\begin{array}{l}0.00964 * \\
(0.00502)\end{array}$ & $\begin{array}{l}0.00486 * \\
(0.00276)\end{array}$ & $\begin{array}{c}0.00462 \\
(0.00340)\end{array}$ & $\begin{array}{r}0.00380 \\
(0.00329)\end{array}$ \\
\hline $\begin{array}{l}\text { N working non-peer - } \\
\text { N non-wrk non-peer (WNP - NWNP) }\end{array}$ & $\begin{array}{l}0.00456 * \\
(0.00276)\end{array}$ & $\begin{array}{c}0.00480 \\
(0.00326)\end{array}$ & $\begin{array}{c}0.00167 \\
(0.00253)\end{array}$ & $\begin{array}{c}0.00462 \\
(0.00356)\end{array}$ & $\begin{array}{c}0.00354 \\
(0.00286)\end{array}$ & $\begin{array}{c}0.00333 \\
(0.00245)\end{array}$ \\
\hline $\begin{array}{l}{[\mathrm{WP}-\mathrm{NWP}]-[\mathrm{WNP}-\mathrm{NWNP}]} \\
(1 \text {-tail P-value })\end{array}$ & $\begin{array}{l}-0.0020 \\
(0.727)\end{array}$ & $\begin{array}{l}0.0008 \\
(0.576)\end{array}$ & $\begin{array}{l}0.0080^{*} \\
(0.081)\end{array}$ & $\begin{array}{l}0.0002 \\
(0.476)\end{array}$ & $\begin{array}{l}0.0011 \\
(0.396)\end{array}$ & $\begin{array}{l}0.0005 \\
(0.447)\end{array}$ \\
\hline Person Fixed Effects & 2,272 & 2,272 & 2,272 & 2,272 & 2,272 & 2,272 \\
\hline$\%$ Neighbors that are Peers & $50.0 \%$ & $72.5 \%$ & $34.4 \%$ & $53.3 \%$ & $38.9 \%$ & $40.3 \%$ \\
\hline Mean Peer Env & 2.11 & 6.36 & 4.11 & 4.65 & 3.56 & 3.47 \\
\hline Mean Non-Peer Env & 2.11 & -1.73 & 1.13 & 1.11 & 1.74 & 1.99 \\
\hline R-square & 0.587 & 0.588 & 0.588 & 0.588 & 0.587 & 0.587 \\
\hline Observations & 5,409 & 5,409 & 5,409 & 5,409 & 5,409 & 5,409 \\
\hline \multicolumn{7}{|c|}{ PANEL B - WOMEN } \\
\hline \multirow{3}{*}{ Peer Group Definition } & & All Ages & & & & \\
\hline & Random & $25-60$ & Gender & Married & Education & Child \\
\hline & (1) & $(2)$ & (3) & (4) & $(5)$ & (6) \\
\hline $\begin{array}{l}\text { N working peer - } \\
\text { N non-wrk peer (WP - NWP) }\end{array}$ & $\begin{array}{c}0.00127 \\
(0.00292)\end{array}$ & $\begin{array}{l}0.00637 * * \\
(0.00305)\end{array}$ & $\begin{array}{l}0.00887 * * \\
(0.00383)\end{array}$ & $\begin{array}{c}0.00523 \\
(0.00338)\end{array}$ & $\begin{array}{l}0.00720^{*} \\
(0.00399)\end{array}$ & $\begin{array}{l}0.00633^{*} \\
(0.00349)\end{array}$ \\
\hline $\begin{array}{l}\mathrm{N} \text { working non-peer - } \\
\mathrm{N} \text { non-wrk non-peer (WNP - NWNP) }\end{array}$ & $\begin{array}{c}0.00515 \\
(0.00313)\end{array}$ & $\begin{array}{l}-0.000943 \\
(0.00381)\end{array}$ & $\begin{array}{l}0.000744 \\
(0.00373)\end{array}$ & $\begin{array}{c}0.00557 \\
(0.00373)\end{array}$ & $\begin{array}{c}0.00146 \\
(0.00334)\end{array}$ & $\begin{array}{l}-0.000416 \\
(0.00339)\end{array}$ \\
\hline $\begin{array}{l}{[\mathrm{WP}-\mathrm{NWP}]-[\mathrm{WNP}-\mathrm{NWNP}]} \\
(1 \text {-tail P-value })\end{array}$ & $\begin{array}{l}-0.0039 \\
(0.848)\end{array}$ & $\begin{array}{l}0.0073 * \\
(0.066)\end{array}$ & $\begin{array}{l}0.0081^{*} \\
(0.065)\end{array}$ & $\begin{array}{l}-0.0003 \\
(0.530)\end{array}$ & $\begin{array}{l}0.0057 \\
(0.120)\end{array}$ & $\begin{array}{l}0.0067^{*} \\
(0.052)\end{array}$ \\
\hline Person Fixed Effects & 2,608 & 2,608 & 2,608 & 2,608 & 2,608 & 2,608 \\
\hline$\%$ Neighbors that are Peers & $50.0 \%$ & $72.2 \%$ & $39.0 \%$ & $51.2 \%$ & $39.1 \%$ & $40.2 \%$ \\
\hline Mean Peer Env & 2.00 & 6.12 & 2.19 & 4.31 & 3.37 & 3.33 \\
\hline Mean Non-Peer Env & 1.99 & -1.73 & 3.34 & 1.19 & 1.73 & 1.91 \\
\hline R-square & 0.700 & 0.701 & 0.701 & 0.701 & 0.701 & 0.701 \\
\hline Observations & 6,252 & 6,252 & 6,252 & 6,252 & 6,252 & 6,252 \\
\hline
\end{tabular}

\footnotetext{
${ }^{\text {a }}$ Sample includes only individuals age 25-60 present in two consecutive surveys and within the 25-60 age range in both surveys. One * indicates significant at the 10 percent level; two at $5 \%$ level; three at $1 \%$ level. All models also include year fixed effects and the additional individual and neighborhood controls reported in Table 2.
} 
Table 3b: Restricted Model With Actual Neighbor Work Status ${ }^{a}$ (standard errors clustered at the neighborhood level in parentheses)

\begin{tabular}{|c|c|c|c|c|c|c|c|}
\hline \multicolumn{8}{|c|}{ PANEL A - MEN } \\
\hline \multirow[b]{2}{*}{ Peer Group Definition } & \multirow[b]{2}{*}{ Gen-Mar } & \multirow[b]{2}{*}{ Gen-Educ } & \multirow[b]{2}{*}{ Gen-Child } & \multirow{2}{*}{$\begin{array}{c}\text { Gen } \\
\text { Mar-Educ }\end{array}$} & \multirow{2}{*}{$\begin{array}{c}\text { Gen } \\
\text { Mar-Child } \\
\end{array}$} & \multirow{2}{*}{$\begin{array}{c}\text { Gen } \\
\text { Ed-Child }\end{array}$} & \multirow{2}{*}{$\begin{array}{l}\text { Gen-Mar } \\
\text { Ed-Child }\end{array}$} \\
\hline & & & & & & & \\
\hline $\begin{array}{l}\text { N working peer - } \\
\text { N non-wrk peer (WP - NWP) }\end{array}$ & $\begin{array}{c}0.00833 \\
(0.00523)\end{array}$ & $\begin{array}{l}0.0117 * * \\
(0.00527)\end{array}$ & $\begin{array}{c}0.00730 \\
(0.00556)\end{array}$ & $\begin{array}{l}0.00929 * \\
(0.00546)\end{array}$ & $\begin{array}{c}0.00902 \\
(0.00584)\end{array}$ & $\begin{array}{c}0.00861 \\
(0.00623)\end{array}$ & $\begin{array}{c}0.00931 \\
(0.00666)\end{array}$ \\
\hline $\begin{array}{l}{[\mathrm{WP}-\mathrm{NWP}]-[\mathrm{WNP}-\mathrm{NWNP}]} \\
(1 \text {-tail P-value })\end{array}$ & $\begin{array}{l}0.0052 \\
(0.179)\end{array}$ & $\begin{array}{c}0.0090 * * \\
(0.046)\end{array}$ & $\begin{array}{l}0.0040 \\
(0.228)\end{array}$ & $\begin{array}{l}0.0056 \\
(0.150)\end{array}$ & $\begin{array}{l}0.0056 \\
(0.160)\end{array}$ & $\begin{array}{l}0.0051 \\
(0.198)\end{array}$ & $\begin{array}{l}0.0056 \\
(0.192)\end{array}$ \\
\hline Person Fixed Effects & 2,272 & 2,272 & 2,272 & 2,272 & 2,272 & 2,272 & 2,272 \\
\hline$\%$ Neighbors that are Peers & $26.1 \%$ & $18.9 \%$ & $19.2 \%$ & $14.5 \%$ & $15.2 \%$ & $10.8 \%$ & $8.7 \%$ \\
\hline Observations & 5,409 & 5,409 & 5,409 & 5,409 & 5,409 & 5,409 & 5,409 \\
\hline \multicolumn{8}{|c|}{ PANEL B - WOMEN } \\
\hline \multirow[t]{2}{*}{ Peer Group Definition } & Gen-Mar & Gen-Educ & Gen-Child & $\begin{array}{c}\text { Gen } \\
\text { Mar-Educ } \\
\end{array}$ & $\begin{array}{c}\text { Gen } \\
\text { Mar-Child } \\
\end{array}$ & $\begin{array}{c}\text { Gen } \\
\text { Ed-Child } \\
\end{array}$ & $\begin{array}{l}\text { Gen-Mar } \\
\text { Ed-Child } \\
\end{array}$ \\
\hline & (1) & (2) & (3) & (4) & $(5)$ & (6) & (7) \\
\hline $\begin{array}{l}\text { N working peer - } \\
\text { N non-wrk peer (WP - NWP) }\end{array}$ & $\begin{array}{l}0.00843 * \\
(0.00472)\end{array}$ & $\begin{array}{l}0.0111 * * \\
(0.00521)\end{array}$ & $\begin{array}{l}0.0105 * * \\
(0.00482)\end{array}$ & $\begin{array}{c}0.0101 \\
(0.00623)\end{array}$ & $\begin{array}{c}0.0104 * \\
(0.00594)\end{array}$ & $\begin{array}{l}0.0143 * * \\
(0.00652)\end{array}$ & $\begin{array}{l}0.0157 * * \\
(0.00777)\end{array}$ \\
\hline $\begin{array}{l}\text { N working non-peer - } \\
\text { N non-wrk non-peer (WNP - NWNP) }\end{array}$ & $\begin{array}{c}0.00213 \\
(0.00302)\end{array}$ & $\begin{array}{c}0.00200 \\
(0.00278)\end{array}$ & $\begin{array}{l}0.000429 \\
(0.00291)\end{array}$ & $\begin{array}{c}0.00234 \\
(0.00266)\end{array}$ & $\begin{array}{c}0.00169 \\
(0.00270)\end{array}$ & $\begin{array}{c}0.00156 \\
(0.00258)\end{array}$ & $\begin{array}{c}0.00176 \\
(0.00254)\end{array}$ \\
\hline Mean Non-Peer Env & 3.66 & 3.65 & 3.77 & 3.89 & 3.95 & 3.99 & 4.10 \\
\hline R-square & 0.701 & 0.701 & 0.701 & 0.701 & 0.701 & 0.701 & 0.701 \\
\hline Observations & 6,252 & 6,252 & 6,252 & 6,252 & 6,252 & 6,252 & 6,252 \\
\hline
\end{tabular}


Table 4: Unrestricted Model With Actual Neighbor Work Status ${ }^{\text {a }}$ (standard errors clustered at the neighborhood level in parentheses)

\begin{tabular}{|c|c|c|c|c|c|c|c|}
\hline \multicolumn{8}{|c|}{ PANEL A -MEN } \\
\hline Peer Group Definition & Gender & Child & Gen-Educ & Gen-Child & $\begin{array}{c}\text { Gen } \\
\text { Mar-Child } \\
\end{array}$ & $\begin{array}{c}\text { Gen } \\
\text { Ed-Child }\end{array}$ & $\begin{array}{l}\text { Gen-Mar } \\
\text { Ed-Child }\end{array}$ \\
\hline & $(1)$ & $(2)$ & (3) & (4) & $(5)$ & $(6)$ & (7) \\
\hline $\mathrm{N}$ working peer (WP) & $\begin{array}{c}0.00250 \\
(0.00611)\end{array}$ & $\begin{array}{l}-0.00166 \\
(0.00408)\end{array}$ & $\begin{array}{c}0.00626 \\
(0.00641)\end{array}$ & $\begin{array}{c}-0.00270 \\
(0.00535)\end{array}$ & $\begin{array}{c}-0.00205 \\
(0.00553)\end{array}$ & $\begin{array}{c}0.00175 \\
(0.00639)\end{array}$ & $\begin{array}{c}0.00104 \\
(0.00679)\end{array}$ \\
\hline $\mathrm{N}$ working non-peer (WNP) & $\begin{array}{c}-0.00500 \\
(0.00493)\end{array}$ & $\begin{array}{r}-0.000848 \\
(0.00378)\end{array}$ & $\begin{array}{l}-0.00425 \\
(0.00397)\end{array}$ & $\begin{array}{l}-0.00172 \\
(0.00354)\end{array}$ & $\begin{array}{l}-0.00161 \\
(0.00341)\end{array}$ & $\begin{array}{l}-0.00162 \\
(0.00360)\end{array}$ & $\begin{array}{r}-0.000860 \\
(0.00345)\end{array}$ \\
\hline N non-working non-peer (NWNP) & $\begin{array}{c}-0.00854 \\
(0.00635)\end{array}$ & $\begin{array}{l}-0.00557 \\
(0.00413)\end{array}$ & $\begin{array}{c}-0.0106^{* *} \\
(0.00504)\end{array}$ & $\begin{array}{c}-0.00667 \\
(0.00444)\end{array}$ & $\begin{array}{l}-0.00631 \\
(0.00426)\end{array}$ & $\begin{array}{c}-0.00870^{* *} \\
(0.00436)\end{array}$ & $\begin{array}{c}-0.00781 * \\
(0.00421)\end{array}$ \\
\hline N non-working peer (NWP) & $\begin{array}{c}-0.0205^{*} \\
(0.0119)\end{array}$ & $\begin{array}{l}-0.0133^{*} \\
(0.00777)\end{array}$ & $\begin{array}{l}-0.0195 \\
(0.0160)\end{array}$ & $\begin{array}{c}-0.0325^{*} \\
(0.0170)\end{array}$ & $\begin{array}{c}-0.0414 * * \\
(0.0188)\end{array}$ & $\begin{array}{c}-0.0259 \\
(0.0220)\end{array}$ & $\begin{array}{c}-0.0369 \\
(0.0249) \\
\end{array}$ \\
\hline Person Fixed Effects & 2,272 & 2,272 & 2,272 & 2,272 & 2,272 & 2,272 & 2,272 \\
\hline$\%$ Neighbors that are Peers & $34.4 \%$ & $40.3 \%$ & $18.9 \%$ & $19.2 \%$ & $15.2 \%$ & $10.8 \%$ & $8.7 \%$ \\
\hline Mean WP & 4.7 & 4.8 & 2.6 & 2.6 & 2.1 & 1.5 & 1.2 \\
\hline Mean WNP & 4.4 & 4.4 & 6.8 & 6.8 & 7.4 & 8.0 & 8.3 \\
\hline Mean NWNP & 3.3 & 2.4 & 4.2 & 4.2 & 4.4 & 4.6 & 4.7 \\
\hline Mean NWP & 0.6 & 1.3 & 0.3 & 0.3 & 0.2 & 0.2 & 0.1 \\
\hline R-square & 0.589 & 0.588 & 0.589 & 0.589 & 0.590 & 0.588 & 0.589 \\
\hline Observations & 5,409 & 5,409 & 5,409 & 5,409 & 5,409 & 5,409 & 5,409 \\
\hline \multicolumn{8}{|c|}{ PANEL B -WOMEN } \\
\hline \multirow[t]{2}{*}{ Peer Group Definition } & Gender & Child & Gen-Educ & Gen-Child & $\begin{array}{c}\text { Gen } \\
\text { Mar-Child } \\
\end{array}$ & $\begin{array}{c}\text { Gen } \\
\text { Ed-Child }\end{array}$ & $\begin{array}{l}\text { Gen-Mar } \\
\text { Ed-Child }\end{array}$ \\
\hline & $(1)$ & $(2)$ & $(3)$ & $(4)$ & $(5)$ & $(6)$ & $(7)$ \\
\hline $\mathrm{N}$ working peer (WP) & $\begin{array}{c}0.00925 \\
(0.00795)\end{array}$ & $\begin{array}{c}0.00353 \\
(0.00576)\end{array}$ & $\begin{array}{c}0.00784 \\
(0.00766)\end{array}$ & $\begin{array}{c}0.00758 \\
(0.00744)\end{array}$ & $\begin{array}{c}0.00309 \\
(0.00845)\end{array}$ & $\begin{array}{c}0.0139 \\
(0.00922)\end{array}$ & $\begin{array}{c}0.0116 \\
(0.0103)\end{array}$ \\
\hline $\mathrm{N}$ working non-peer (WNP) & $\begin{array}{c}-0.00429 \\
(0.00774)\end{array}$ & $\begin{array}{l}-6.63 e-05 \\
(0.00556)\end{array}$ & $\begin{array}{l}0.000922 \\
(0.00555)\end{array}$ & $\begin{array}{c}0.00141 \\
(0.00537)\end{array}$ & $\begin{array}{c}0.00123 \\
(0.00524)\end{array}$ & $\begin{array}{c}0.00239 \\
(0.00521)\end{array}$ & $\begin{array}{c}0.00189 \\
(0.00528)\end{array}$ \\
\hline N non-working non-peer (NWNP) & $\begin{array}{c}-0.00723 \\
(0.00860)\end{array}$ & $\begin{array}{c}0.00476 \\
(0.00596)\end{array}$ & $\begin{array}{c}-0.00300 \\
(0.00612)\end{array}$ & $\begin{array}{c}0.00109 \\
(0.00579)\end{array}$ & $\begin{array}{c}-0.00162 \\
(0.00571)\end{array}$ & $\begin{array}{r}-0.000557 \\
(0.00561)\end{array}$ & $\begin{array}{c}-0.00142 \\
(0.00564)\end{array}$ \\
\hline $\mathrm{N}$ non-working peer (NWP) & $\begin{array}{c}-0.00790 \\
(0.00956)\end{array}$ & $\begin{array}{l}-0.0164 * \\
(0.00876)\end{array}$ & $\begin{array}{c}-0.0154 \\
(0.0105)\end{array}$ & $\begin{array}{c}-0.0158 \\
(0.0103)\end{array}$ & $\begin{array}{l}-0.0216^{*} \\
(0.0119)\end{array}$ & $\begin{array}{c}-0.0155 \\
(0.0121)\end{array}$ & $\begin{array}{c}-0.0222 \\
(0.0138)\end{array}$ \\
\hline Person Fixed Effects & 2,608 & 2,608 & 2,608 & 2,608 & 2,608 & 2,608 & 2,608 \\
\hline$\%$ Neighbors that are Peers & $39.0 \%$ & $40.2 \%$ & $21.3 \%$ & $21.8 \%$ & $15.3 \%$ & $12.0 \%$ & $8.6 \%$ \\
\hline Mean WP & 4.0 & 4.6 & 2.2 & 2.2 & 1.5 & 1.2 & 0.9 \\
\hline Mean WNP & 5.0 & 4.3 & 7.0 & 7.0 & 7.7 & 8.1 & 8.5 \\
\hline Mean NWNP & 1.6 & 2.4 & 3.3 & 3.2 & 3.8 & 4.1 & 4.3 \\
\hline Mean NWP & 1.8 & 1.3 & 1.0 & 1.0 & 0.8 & 0.6 & 0.4 \\
\hline R-square & 0.701 & 0.701 & 0.701 & 0.701 & 0.701 & 0.701 & 0.701 \\
\hline Observations & 6,252 & 6,252 & 6,252 & 6,252 & 6,252 & 6,252 & 6,252 \\
\hline
\end{tabular}

${ }^{a}$ Sample includes only individuals age 25-60 present in two consecutive surveys and within the 25-60 age range in both surveys. One

* indicates significant at the 10 percent level; two at $5 \%$ level; three at $1 \%$ level. All models also include year fixed effects and the additional individual and neighborhood controls reported in Table 2. 
Table 5a: Restricted Model Proxying With MSA-Level Employment Rates ${ }^{\mathrm{a}}$ (standard errors clustered at the neighborhood level in parentheses)

\begin{tabular}{|c|c|c|c|c|c|c|c|}
\hline \multicolumn{8}{|c|}{ PANEL A - MEN } \\
\hline Peer Group Definition & Gender & Child & Gen-Educ & Gen-Child & $\begin{array}{c}\text { Gen } \\
\text { Mar-Child } \\
\end{array}$ & $\begin{array}{c}\text { Gen } \\
\text { Ed-Child }\end{array}$ & $\begin{array}{l}\text { Gen-Mar } \\
\text { Ed-Child }\end{array}$ \\
\hline & (1) & (2) & (3) & (4) & (5) & (6) & (7) \\
\hline $\begin{array}{l}\text { N working peer - } \\
\text { N non-wrk peer (WP - NWP) }\end{array}$ & $\begin{array}{l}-0.00556 \\
(0.00875)\end{array}$ & $\begin{array}{l}-0.00743 \\
(0.00656)\end{array}$ & $\begin{array}{c}0.00307 \\
(0.00921)\end{array}$ & $\begin{array}{l}-0.00839 \\
(0.00797)\end{array}$ & $\begin{array}{l}-0.00904 \\
(0.00821)\end{array}$ & $\begin{array}{l}-0.00321 \\
(0.00877)\end{array}$ & $\begin{array}{l}-0.00260 \\
(0.00895)\end{array}$ \\
\hline $\begin{array}{l}\text { N working non-peer - } \\
\text { N non-wrk non-peer (WNP - NWNP) }\end{array}$ & $\begin{array}{l}-0.00502 \\
(0.0152)\end{array}$ & $\begin{array}{l}-0.00640 \\
(0.00715)\end{array}$ & $\begin{array}{l}-0.0129 \\
(0.0109)\end{array}$ & $\begin{array}{l}-0.00890 \\
(0.0102)\end{array}$ & $\begin{array}{l}-0.00807 \\
(0.00894)\end{array}$ & $\begin{array}{l}-0.00854 \\
(0.00955)\end{array}$ & $\begin{array}{l}-0.00602 \\
(0.00872)\end{array}$ \\
\hline $\begin{array}{l}{[\mathrm{WP}-\mathrm{NWP}]-[\mathrm{WNP}-\mathrm{NWNP}]} \\
\text { (1-tail P-value) }\end{array}$ & $\begin{array}{l}0.0065 \\
(0.513)\end{array}$ & $\begin{array}{l}0.0006 \\
(0.568)\end{array}$ & $\begin{array}{l}0.0017 \\
(0.108)\end{array}$ & $\begin{array}{l}0.0022 \\
(0.479)\end{array}$ & $\begin{array}{l}0.0007 \\
(0.542)\end{array}$ & $\begin{array}{l}0.0008 \\
(0.303)\end{array}$ & $\begin{array}{r}-0.0002 \\
(0.367)\end{array}$ \\
\hline Person Fixed Effects & 2,272 & 2,272 & 2,272 & 2,272 & 2,272 & 2,272 & 2,272 \\
\hline$\%$ Neighbors that are Peers & $34.4 \%$ & $40.3 \%$ & $18.9 \%$ & $19.2 \%$ & $15.2 \%$ & $10.8 \%$ & $8.7 \%$ \\
\hline Mean Peer Env & 3.49 & 3.12 & 2.02 & 1.95 & 1.61 & 1.15 & 0.97 \\
\hline Mean Non-Peer Env & 1.34 & 2.28 & 2.77 & 3.01 & 3.35 & 3.64 & 3.84 \\
\hline R-square & 0.587 & 0.587 & 0.587 & 0.587 & 0.587 & 0.587 & 0.588 \\
\hline Observations & 5,409 & 5,409 & 5,409 & 5,409 & 5,409 & 5,409 & 5,409 \\
\hline \multicolumn{8}{|c|}{ PANEL B - WOMEN } \\
\hline \multirow[t]{2}{*}{ Peer Group Definition } & Gender & Child & Gen-Educ & Gen-Child & $\begin{array}{c}\text { Gen } \\
\text { Mar-Child }\end{array}$ & $\begin{array}{c}\text { Gen } \\
\text { Ed-Child }\end{array}$ & $\begin{array}{l}\text { Gen-Mar } \\
\text { Ed-Child }\end{array}$ \\
\hline & (1) & (2) & (3) & (4) & (5) & (6) & (7) \\
\hline $\begin{array}{l}\text { N working peer - } \\
\text { N non-wrk peer (WP - NWP) }\end{array}$ & $\begin{array}{c}0.0197 \\
(0.0168)\end{array}$ & $\begin{array}{c}-0.000806 \\
(0.0102)\end{array}$ & $\begin{array}{c}0.0160 \\
(0.0133)\end{array}$ & $\begin{array}{l}0.0254^{*} \\
(0.0152)\end{array}$ & $\begin{array}{c}0.0141 \\
(0.0167)\end{array}$ & $\begin{array}{c}0.0336^{* *} \\
(0.0159)\end{array}$ & $\begin{array}{c}0.0218 \\
(0.0172)\end{array}$ \\
\hline $\begin{array}{l}\text { N working non-peer - } \\
\text { N non-wrk non-peer (WNP - NWNP) }\end{array}$ & $\begin{array}{r}-0.00478 \\
(0.0137)\end{array}$ & $\begin{array}{l}-0.00270 \\
(0.0114)\end{array}$ & $\begin{array}{l}0.00285 \\
(0.0141)\end{array}$ & $\begin{array}{l}0.00761 \\
(0.0116)\end{array}$ & $\begin{array}{l}0.00470 \\
(0.0113)\end{array}$ & $\begin{array}{l}0.00696 \\
(0.0120)\end{array}$ & $\begin{array}{l}0.00523 \\
(0.0116)\end{array}$ \\
\hline $\begin{array}{l}{[\mathrm{WP}-\mathrm{NWP}]-[\mathrm{WNP}-\mathrm{NWNP}]} \\
(1 \text {-tail P-value })\end{array}$ & $\begin{array}{l}0.0245 \\
(0.105)\end{array}$ & $\begin{array}{l}0.0019 \\
(0.402)\end{array}$ & $\begin{array}{l}0.0132 \\
(0.196)\end{array}$ & $\begin{array}{c}0.0178 * \\
(0.090)\end{array}$ & $\begin{array}{l}0.0094 \\
(0.267)\end{array}$ & $\begin{array}{c}0.0266^{* *} \\
(0.040)\end{array}$ & $\begin{array}{l}0.0166 \\
(0.174)\end{array}$ \\
\hline Person Fixed Effects & 2,608 & 2,608 & 2,608 & 2,608 & 2,608 & 2,608 & 2,608 \\
\hline$\%$ Neighbors that are Peers & $39.0 \%$ & $40.2 \%$ & $21.3 \%$ & $21.8 \%$ & $15.3 \%$ & $12.0 \%$ & $8.6 \%$ \\
\hline Mean Peer Env & 2.28 & 3.06 & 1.35 & 1.19 & 0.79 & 0.71 & 0.48 \\
\hline Mean Non-Peer Env & 3.14 & 2.24 & 3.36 & 3.63 & 3.80 & 3.85 & 4.01 \\
\hline R-square & 0.700 & 0.700 & 0.700 & 0.701 & 0.700 & 0.701 & 0.700 \\
\hline Observations & 6,252 & 6,252 & 6,252 & 6,252 & 6,252 & 6,252 & 6,252 \\
\hline
\end{tabular}


Table 5b: Unrestricted Model Proxying for With MSA-Level Employment Rates ${ }^{\text {a }}$ (standard errors clustered at the neighborhood level in parentheses)

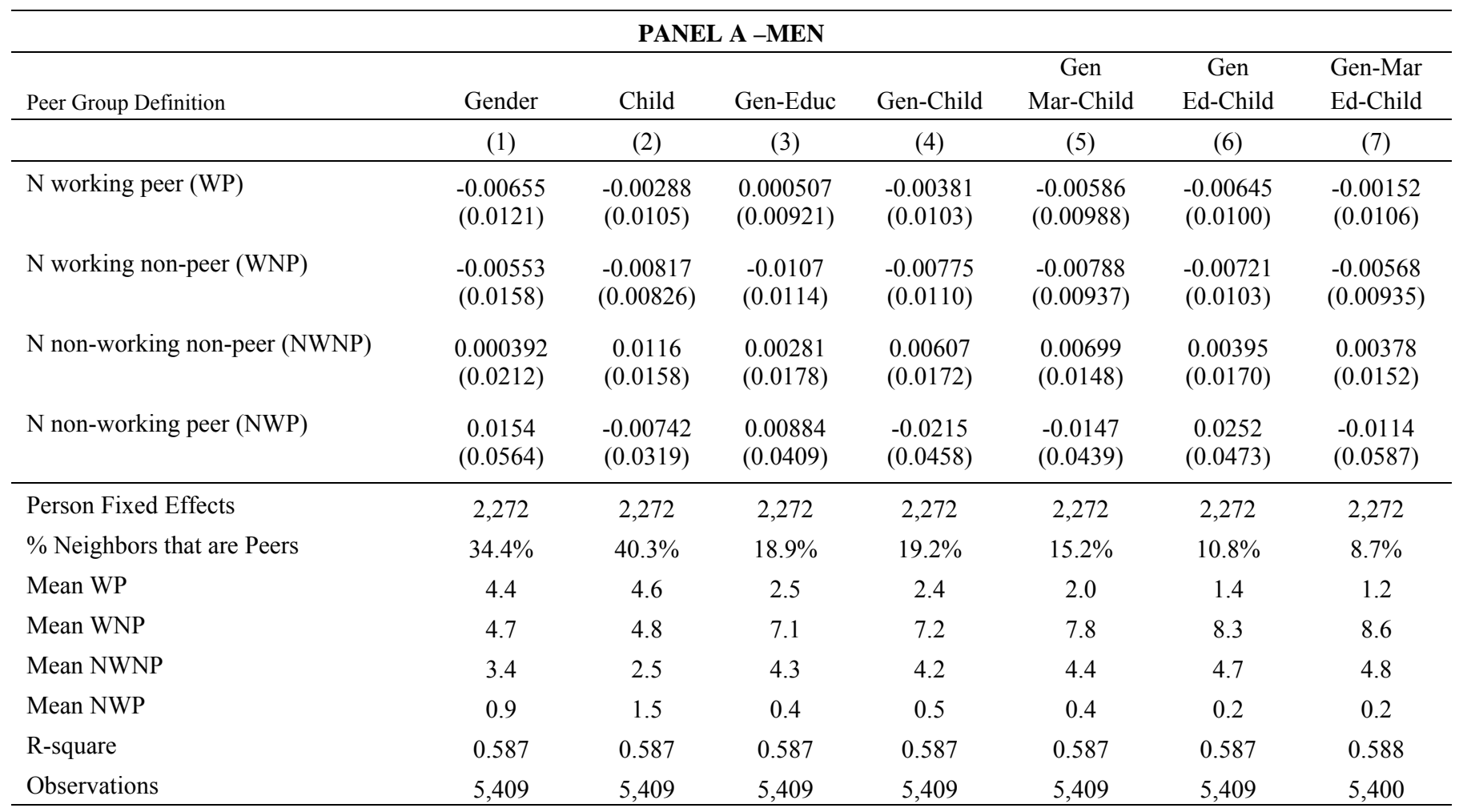

PANEL B -WOMEN

\begin{tabular}{|c|c|c|c|c|c|c|c|}
\hline Peer Group Definition & Gender & Child & Gen-Educ & Gen-Child & $\begin{array}{c}\text { Gen } \\
\text { Mar-Child }\end{array}$ & $\begin{array}{c}\text { Gen } \\
\text { Ed-Child }\end{array}$ & $\begin{array}{l}\text { Gen-Mar } \\
\text { Ed-Child }\end{array}$ \\
\hline & (1) & (2) & (3) & (4) & (5) & (6) & (7) \\
\hline N working non-peer (WNP) & $\begin{array}{c}-0.000450 \\
(0.0160)\end{array}$ & $\begin{array}{l}-0.0120 \\
(0.0127)\end{array}$ & $\begin{array}{l}0.00231 \\
(0.0157)\end{array}$ & $\begin{array}{c}-0.000490 \\
(0.0124)\end{array}$ & $\begin{array}{l}-0.00459 \\
(0.0120)\end{array}$ & $\begin{array}{c}0.000766 \\
(0.0127)\end{array}$ & $\begin{array}{c}0.000203 \\
(0.0122)\end{array}$ \\
\hline N non-working peer (NWP) & $\begin{array}{l}-0.0591 \\
(0.0450)\end{array}$ & $\begin{array}{l}-0.0496 \\
(0.0415)\end{array}$ & $\begin{array}{l}-0.0551 * \\
(0.0308)\end{array}$ & $\begin{array}{c}-0.0948 * * * \\
(0.0350)\end{array}$ & $\begin{array}{l}-0.0650 * \\
(0.0339)\end{array}$ & $\begin{array}{c}-0.0894 * * * \\
(0.0335)\end{array}$ & $\begin{array}{c}-0.0590 * \\
(0.0356)\end{array}$ \\
\hline Person Fixed Effects & 2,608 & 2,608 & 2,608 & 2,608 & 2,608 & 2,608 & 2,608 \\
\hline Mean NWNP & 1.9 & 2.4 & 3.6 & 3.5 & 4.1 & 4.3 & 4.6 \\
\hline Mean NWP & 1.7 & 1.4 & 0.9 & 1.0 & 0.8 & 0.5 & 0.4 \\
\hline R-square & 0.700 & 0.701 & 0.701 & 0.702 & 0.701 & 0.702 & 0.701 \\
\hline Observations & 6,252 & 6,252 & 6,252 & 6,252 & 6,252 & 6,252 & 6,252 \\
\hline
\end{tabular}

${ }^{a}$ Sample includes only individuals age 25-60 present in two consecutive surveys and within the 25-60 age range in both surveys. One * indicates significant at the 10 percent level; two at $5 \%$ level; three at $1 \%$ level. All models also include year fixed effects and the additional individual and neighborhood controls reported in Table 2 (including the MSA employment rate for the survey year in question). 
Table 6a: Robustness - All Models Proxy With MSA-Level Employment Rates

(standard errors clustered at the neighborhood level in parentheses)

\begin{tabular}{|c|c|c|c|c|c|c|c|c|c|c|c|c|}
\hline & \multicolumn{4}{|c|}{ Single Versus Married Women ${ }^{\mathbf{a}}$} & \multicolumn{4}{|c|}{$\$ 5,000$ Income Cutoff $^{\mathbf{b}}$} & \multicolumn{4}{|c|}{ Main Effects + Interactions ${ }^{c}$} \\
\hline & $\begin{array}{c}\text { Single } \\
\text { Women }\end{array}$ & $\begin{array}{l}\text { Married } \\
\text { Women }\end{array}$ & $\begin{array}{c}\text { Single } \\
\text { Women }\end{array}$ & $\begin{array}{l}\text { Married } \\
\text { Women }\end{array}$ & Men & Women & Men & Women & Men & Women & Men & Women \\
\hline Peer Group Definition & $\begin{array}{l}\text { Gen- } \\
\text { Child }\end{array}$ & $\begin{array}{l}\text { Gen- } \\
\text { Child }\end{array}$ & $\begin{array}{c}\text { Gen } \\
\text { Ed-Child }\end{array}$ & $\begin{array}{c}\text { Gen } \\
\text { Ed-Child }\end{array}$ & $\begin{array}{l}\text { Gen- } \\
\text { Child }\end{array}$ & $\begin{array}{l}\text { Gen- } \\
\text { Child }\end{array}$ & $\begin{array}{c}\text { Gen } \\
\text { Ed-Child }\end{array}$ & $\begin{array}{c}\text { Gen } \\
\text { Ed-Child }\end{array}$ & $\begin{array}{c}\text { Gen } \\
\text { Ed-Child }\end{array}$ & $\begin{array}{c}\text { Gen } \\
\text { Ed-Child }\end{array}$ & $\begin{array}{c}\text { Gen } \\
\text { Ed-Child }\end{array}$ & $\begin{array}{c}\text { Gen } \\
\text { Ed-Child }\end{array}$ \\
\hline & (1) & (2) & (3) & (4) & (5) & (6) & (7) & $(8)$ & (9) & $(10)$ & (11) & (12) \\
\hline WP - NWP & - & - & - & - & - & - & - & - & $\begin{array}{c}-0.0228 \\
(0.0373)\end{array}$ & $\begin{array}{c}0.0525 * * \\
(0.0267)\end{array}$ & - & - \\
\hline WNP - NWNP & - & - & - & - & - & - & - & - & $\begin{array}{c}-0.0341 \\
(0.0269)\end{array}$ & $\begin{array}{r}-0.00281 \\
(0.0372)\end{array}$ & - & - \\
\hline WP & $\begin{array}{c}0.0217 \\
(0.0251)\end{array}$ & $\begin{array}{c}0.0469 * * \\
(0.0226)\end{array}$ & $\begin{array}{c}0.0292 \\
(0.0242)\end{array}$ & $\begin{array}{l}0.0385^{*} \\
(0.0218)\end{array}$ & $\begin{array}{r}-0.00442 \\
(0.0101)\end{array}$ & $\begin{array}{c}0.0410^{* *} \\
(0.0184)\end{array}$ & $\begin{array}{c}-0.00128 \\
(0.0118)\end{array}$ & $\begin{array}{c}0.0385^{*} \\
(0.0218)\end{array}$ & - & - & $\begin{array}{c}-0.00930 \\
(0.0122)\end{array}$ & $\begin{array}{c}0.0357^{*} \\
(0.0187)\end{array}$ \\
\hline WNP & $\begin{array}{l}-0.0157 \\
(0.0214)\end{array}$ & $\begin{array}{c}0.00144 \\
(0.0155)\end{array}$ & $\begin{array}{c}-0.0134 \\
(0.0182)\end{array}$ & $\begin{array}{l}0.00579 \\
(0.0155)\end{array}$ & $\begin{array}{c}-0.00452 \\
(0.0133)\end{array}$ & $\begin{array}{l}0.00670 \\
(0.0146)\end{array}$ & $\begin{array}{r}-0.00213 \\
(0.0130)\end{array}$ & $\begin{array}{c}0.00579 \\
(0.0155)\end{array}$ & - & - & $\begin{array}{l}-0.0283 \\
(0.0199)\end{array}$ & $\begin{array}{r}0.000925 \\
(0.0264)\end{array}$ \\
\hline NWNP & $\begin{array}{c}0.0485 \\
(0.0461)\end{array}$ & $\begin{array}{l}0.00605 \\
(0.0283)\end{array}$ & $\begin{array}{c}0.0196 \\
(0.0370)\end{array}$ & $\begin{array}{l}0.00391 \\
(0.0264)\end{array}$ & $\begin{array}{r}-0.00117 \\
(0.0152)\end{array}$ & $\begin{array}{r}-0.00559 \\
(0.0207)\end{array}$ & $\begin{array}{c}-0.00652 \\
(0.0156)\end{array}$ & $\begin{array}{c}0.00391 \\
(0.0264)\end{array}$ & - & - & $\begin{array}{c}0.0399 \\
(0.0344)\end{array}$ & $\begin{array}{c}0.00655 \\
(0.0489)\end{array}$ \\
\hline NWP & $\begin{array}{c}-0.0890^{*} \\
(0.0516)\end{array}$ & $\begin{array}{c}-0.0824 * \\
(0.0467)\end{array}$ & $\begin{array}{c}-0.0722 \\
(0.0505)\end{array}$ & $\begin{array}{l}-0.0630 \\
(0.0449)\end{array}$ & $\begin{array}{c}-0.0151 \\
(0.0341)\end{array}$ & $\begin{array}{c}-0.0667 * * \\
(0.0270)\end{array}$ & $\begin{array}{l}0.00352 \\
(0.0468)\end{array}$ & $\begin{array}{l}-0.0630 \\
(0.0449)\end{array}$ & - & - & $\begin{array}{c}0.0363 \\
(0.0649)\end{array}$ & $\begin{array}{c}-0.0692 * \\
(0.0374)\end{array}$ \\
\hline N Peers & - & - & - & - & - & - & - & - & $\begin{array}{c}0.0135 \\
(0.0280)\end{array}$ & $\begin{array}{c}-0.0168 \\
(0.0127)\end{array}$ & - & - \\
\hline N Non-Peers & - & - & - & - & - & - & - & - & $\begin{array}{c}0.00581 \\
(0.00822)\end{array}$ & $\begin{array}{c}0.1610 \\
(0.140)\end{array}$ & - & - \\
\hline Emp Rate Peers & - & - & - & - & - & - & - & - & $\begin{array}{l}0.0526 \\
(0.185)\end{array}$ & $\begin{array}{c}0.0037 \\
(0.0126)\end{array}$ & $\begin{array}{l}0.0526 \\
(0.185)\end{array}$ & $\begin{array}{c}0.161 \\
(0.140)\end{array}$ \\
\hline Emp Rate Non-Peers & - & - & - & - & - & - & - & - & $\begin{array}{c}1.235 \\
(0.846)\end{array}$ & $\begin{array}{c}0.0883 \\
(0.942)\end{array}$ & $\begin{array}{c}1.235 \\
(0.846)\end{array}$ & $\begin{array}{l}0.0883 \\
(0.942)\end{array}$ \\
\hline R-square & 0.807 & 0.680 & 0.806 & 0.680 & 0.586 & 0.709 & 0.586 & 0.680 & 0.587 & 0.702 & 0.587 & 0.702 \\
\hline Observations & 1,381 & 4,577 & 1,381 & 4,577 & 5,409 & 6,252 & 5,409 & 6,252 & 5,409 & 6,252 & 5,409 & 6,252 \\
\hline
\end{tabular}


Table 6b: Percent change in the probability that two individuals live in the same neighborhood cluster (relative to the unconditional probability) in response to a 1 -unit (100 percentage point) difference in their Work regression residuals.

\begin{tabular}{|c|c|c|c|c|c|c|c|}
\hline & Gender & Child & Gen-Educ & Gen-Child & $\begin{array}{c}\text { Gen } \\
\text { Mar-Child }\end{array}$ & $\begin{array}{c}\text { Gen } \\
\text { Ed-Child }\end{array}$ & $\begin{array}{l}\text { Gen-Mar } \\
\text { Ed-Child }\end{array}$ \\
\hline & (1) & (2) & (3) & (4) & (5) & (6) & (7) \\
\hline \multicolumn{8}{|l|}{ MEN } \\
\hline Table 5a Models ${ }^{\mathrm{a}}$ & $-13.17 \% * *$ & $-12.47 \% * *$ & $-12.98 \% * *$ & $-13.10 \% * *$ & $-13.04 \% * *$ & $-12.85 \% * *$ & $-13.04 \% * *$ \\
\hline Table 5b Models ${ }^{\mathrm{a}}$ & $-13.17 \% * *$ & $-12.54 \% * *$ & $-13.17 \% * *$ & $-13.29 \% * *$ & $-13.23 \% * *$ & $-12.79 \% * *$ & $-13.17 \% * *$ \\
\hline \multicolumn{8}{|l|}{ WOMEN } \\
\hline Table 5a Models ${ }^{\mathrm{a}}$ & $-4.57 \%$ & $-3.32 \%$ & $-3.58 \%$ & $-3.98 \%$ & $-3.58 \%$ & $-3.70 \%$ & $-3.41 \%$ \\
\hline Table 5b Models ${ }^{\mathrm{a}}$ & $-4.92 \%$ & $-4.22 \%$ & $-3.93 \%$ & $-5.33 \%$ & $-4.41 \%$ & $-4.73 \%$ & $-3.83 \%$ \\
\hline
\end{tabular}




\section{Appendix: Supplemental Tables}

Table A-1: Summary Statistics for Table 6a ${ }^{a}$

\begin{tabular}{|c|c|c|c|c|c|c|c|c|}
\hline \multicolumn{9}{|c|}{ Panel A: Employed if Earnings in the Previous Year Exceeds \$0 (Year 2013 \$) } \\
\hline & \multicolumn{2}{|c|}{$\begin{array}{l}\text { All Men } \\
\text { Sample }\end{array}$} & \multicolumn{2}{|c|}{$\begin{array}{l}\text { All Women } \\
\text { Sample }\end{array}$} & \multicolumn{2}{|c|}{$\begin{array}{c}\text { Married Women } \\
\text { Sample }\end{array}$} & \multicolumn{2}{|c|}{$\begin{array}{l}\text { Single Women } \\
\text { Sample }\end{array}$} \\
\hline Level based on pooled surveys & Mean & Std.Dev & Mean & Std.Dev & Mean & Std.Dev & Mean & Std.Dev \\
\hline Work Last Year & 0.891 & 0.311 & 0.697 & 0.460 & 0.672 & 0.470 & 0.764 & 0.425 \\
\hline Change between adjacent surveys & Mean & Std.Dev & Mean & Std.Dev & Mean & Std.Dev & Mean & Std.Dev \\
\hline Work Last Year & -0.024 & 0.364 & 0.002 & 0.456 & 0.001 & 0.479 & -0.004 & 0.355 \\
\hline Percent that change work status & $16.7 \%$ & - & $26.5 \%$ & - & $29.6 \%$ & - & $15.9 \%$ & - \\
\hline Number that change work status & 379 & - & 690 & - & 565 & - & 96 & - \\
\hline \multicolumn{9}{|c|}{ Panel B: Employed if Earnings in the Previous Year Exceeds \$5,000 (Year 2013 \$) } \\
\hline & \multicolumn{2}{|c|}{$\begin{array}{l}\text { All Men } \\
\text { Sample }\end{array}$} & \multicolumn{2}{|c|}{$\begin{array}{l}\text { All Women } \\
\text { Sample }\end{array}$} & \multicolumn{2}{|c|}{$\begin{array}{l}\text { Married Women } \\
\text { Sample }\end{array}$} & \multicolumn{2}{|c|}{$\begin{array}{l}\text { Single Women } \\
\text { Sample }\end{array}$} \\
\hline Level based on pooled surveys & Mean & Std.Dev & Mean & Std.Dev & Mean & Std.Dev & Mean & Std.Dev \\
\hline Work Last Year & 0.880 & 0.325 & 0.651 & 0.477 & 0.619 & 0.486 & 0.736 & 0.441 \\
\hline Change between adjacent surveys & Mean & Std.Dev & Mean & Std.Dev & Mean & Std.Dev & Mean & Std.Dev \\
\hline Work Last Year & -0.026 & 0.380 & 0.005 & 0.468 & 0.003 & 0.485 & 0.000 & 0.386 \\
\hline Percent that change work status & $18.2 \%$ & - & $27.7 \%$ & - & $30.1 \%$ & - & $18.9 \%$ & - \\
\hline Number that change work status & 414 & - & 723 & - & 575 & - & 114 & - \\
\hline
\end{tabular}

${ }^{a}$ Samples include only individuals present in two or more surveys who are age 25-60 in both surveys. 
Table A-2a: Linear Probability Model of Locating in the Same Neighborhood Cluster Controlling for Person Attributes and Residuals from Table 5a ${ }^{a}$ (Robust standard errors in parentheses)

\begin{tabular}{|c|c|c|c|c|c|c|c|}
\hline \multicolumn{8}{|c|}{ PANEL A - MEN } \\
\hline & Gender & Child & Gen-Educ & Gen-Child & $\begin{array}{c}\text { Gen } \\
\text { Mar-Child } \\
\end{array}$ & $\begin{array}{c}\text { Gen } \\
\text { Ed-Child } \\
\end{array}$ & $\begin{array}{l}\text { Gen-Mar } \\
\text { Ed-Child } \\
\end{array}$ \\
\hline & (1) & (2) & (3) & (4) & (5) & (6) & $(7)$ \\
\hline Dif_HS degree/some college & $\begin{array}{c}-0.000228^{* * *} \\
(4.04 \mathrm{e}-05)\end{array}$ & $\begin{array}{c}-0.000228^{* * *} \\
(4.04 \mathrm{e}-05)\end{array}$ & $\begin{array}{c}-0.000228^{* * *} \\
(4.04 \mathrm{e}-05)\end{array}$ & $\begin{array}{c}-0.000228^{* * *} \\
(4.04 \mathrm{e}-05)\end{array}$ & $\begin{array}{c}-0.000228^{* * *} \\
(4.04 \mathrm{e}-05)\end{array}$ & $\begin{array}{c}-0.000228^{* * *} \\
(4.04 \mathrm{e}-05)\end{array}$ & $\begin{array}{c}-0.000228^{* * *} \\
(4.05 \mathrm{e}-05)\end{array}$ \\
\hline Dif_BA degree or more & $\begin{array}{c}-0.000724 * * * \\
(3.94 \mathrm{e}-05)\end{array}$ & $\begin{array}{c}-0.000724 * * * \\
(3.94 \mathrm{e}-05)\end{array}$ & $\begin{array}{c}-0.000724 * * * \\
(3.94 \mathrm{e}-05)\end{array}$ & $\begin{array}{c}-0.000724^{* * *} \\
(3.94 \mathrm{e}-05)\end{array}$ & $\begin{array}{c}-0.000724 * * * \\
(3.94 \mathrm{e}-05)\end{array}$ & $\begin{array}{c}-0.000724^{* * *} \\
(3.94 \mathrm{e}-05)\end{array}$ & $\begin{array}{c}-0.000722 * * * \\
(3.95 \mathrm{e}-05)\end{array}$ \\
\hline Dif_Married & $\begin{array}{c}-0.000817 * * * \\
(3.75 \mathrm{e}-05)\end{array}$ & $\begin{array}{c}-0.000817 * * * \\
(3.75 \mathrm{e}-05)\end{array}$ & $\begin{array}{c}-0.000817 * * * \\
(3.75 \mathrm{e}-05)\end{array}$ & $\begin{array}{c}-0.000817^{* * *} \\
(3.75 \mathrm{e}-05)\end{array}$ & $\begin{array}{c}-0.000817^{* * *} \\
(3.75 \mathrm{e}-05)\end{array}$ & $\begin{array}{c}-0.000817^{* * *} \\
(3.75 \mathrm{e}-05)\end{array}$ & $\begin{array}{c}-0.000822 * * * \\
(3.76 \mathrm{e}-05)\end{array}$ \\
\hline Dif_Child under age 18 & $\begin{array}{c}-0.000190^{* * * *} \\
(3.81 \mathrm{e}-05)\end{array}$ & $\begin{array}{c}-0.000190 * * * \\
(3.81 \mathrm{e}-05)\end{array}$ & $\begin{array}{c}-0.000190 * * * \\
(3.81 \mathrm{e}-05)\end{array}$ & $\begin{array}{c}-0.000190^{* * *} \\
(3.81 \mathrm{e}-05)\end{array}$ & $\begin{array}{c}-0.000190 * * * \\
(3.81 \mathrm{e}-05)\end{array}$ & $\begin{array}{c}-0.000190 * * * \\
(3.81 \mathrm{e}-05)\end{array}$ & $\begin{array}{c}-0.000187 * * * \\
(3.82 \mathrm{e}-05)\end{array}$ \\
\hline Dif_- $1^{\text {st }}$ Stage Residuals & $\begin{array}{c}-0.000209^{* *} \\
(8.29 \mathrm{e}-05)\end{array}$ & $\begin{array}{c}-0.000198^{* *} \\
(8.29 \mathrm{e}-05)\end{array}$ & $\begin{array}{c}-0.000206^{* *} \\
(8.30 \mathrm{e}-05)\end{array}$ & $\begin{array}{c}-0.000208^{* *} \\
(8.29 \mathrm{e}-05)\end{array}$ & $\begin{array}{c}-0.000207^{* *} \\
(8.30 \mathrm{e}-05)\end{array}$ & $\begin{array}{c}-0.000204 * * \\
(8.28 \mathrm{e}-05)\end{array}$ & $\begin{array}{c}-0.000207 * * \\
(8.31 \mathrm{e}-05)\end{array}$ \\
\hline Constant & $\begin{array}{c}0.00262 * * * \\
(4.22 \mathrm{e}-05)\end{array}$ & $\begin{array}{c}0.00262 * * * \\
(4.22 \mathrm{e}-05)\end{array}$ & $\begin{array}{l}0.00262^{* * * *} \\
(4.22 \mathrm{e}-05)\end{array}$ & $\begin{array}{c}0.00262 * * * \\
(4.22 \mathrm{e}-05)\end{array}$ & $\begin{array}{c}0.00262 * * * \\
(4.22 \mathrm{e}-05)\end{array}$ & $\begin{array}{c}0.00262 * * * \\
(4.22 \mathrm{e}-05)\end{array}$ & $\begin{array}{c}0.00262^{* * *} \\
(4.23 \mathrm{e}-05)\end{array}$ \\
\hline Observations & $5,033,350$ & $5,033,350$ & $5,033,350$ & $5,033,350$ & $5,033,350$ & $5,033,350$ & $5,016,312$ \\
\hline \multicolumn{8}{|c|}{ PANEL B - WOMEN } \\
\hline & Gender & Child & Gen-Educ & Gen-Child & $\begin{array}{c}\text { Gen } \\
\text { Mar-Child }\end{array}$ & $\begin{array}{c}\text { Gen } \\
\text { Ed-Child }\end{array}$ & $\begin{array}{l}\text { Gen-Mar } \\
\text { Ed-Child }\end{array}$ \\
\hline & $(1)$ & (2) & (3) & (4) & (5) & (6) & (7) \\
\hline Dif_HS degree/some college & $\begin{array}{c}-0.000191 * * * \\
(3.34 \mathrm{e}-05)\end{array}$ & $\begin{array}{l}-0.000191 * * * \\
(3.34 \mathrm{e}-05)\end{array}$ & $\begin{array}{c}-0.000191 * * * \\
(3.34 \mathrm{e}-05)\end{array}$ & $\begin{array}{c}-0.000191 * * * \\
(3.34 \mathrm{e}-05)\end{array}$ & $\begin{array}{c}-0.000191 * * * \\
(3.34 \mathrm{e}-05)\end{array}$ & $\begin{array}{c}-0.000191 * * * \\
(3.34 \mathrm{e}-05)\end{array}$ & $\begin{array}{c}-0.000191 * * * \\
(3.34 \mathrm{e}-05)\end{array}$ \\
\hline Dif_BA degree or more & $\begin{array}{c}-0.000360^{* * *} \\
(3.32 \mathrm{e}-05)\end{array}$ & $\begin{array}{c}-0.000359 * * * \\
(3.32 \mathrm{e}-05)\end{array}$ & $\begin{array}{c}-0.000359 * * * \\
(3.32 \mathrm{e}-05)\end{array}$ & $\begin{array}{c}-0.000359^{* * *} \\
(3.32 \mathrm{e}-05)\end{array}$ & $\begin{array}{c}-0.000359^{* * *} \\
(3.32 \mathrm{e}-05)\end{array}$ & $\begin{array}{c}-0.000359 * * * \\
(3.32 \mathrm{e}-05)\end{array}$ & $\begin{array}{c}-0.000359 * * * \\
(3.32 \mathrm{e}-05)\end{array}$ \\
\hline Dif_Married & $\begin{array}{c}-0.000853 * * * \\
(3.09 \mathrm{e}-05)\end{array}$ & $\begin{array}{c}-0.000852 * * * \\
(3.09 \mathrm{e}-05)\end{array}$ & $\begin{array}{c}-0.000852 * * * \\
(3.09 \mathrm{e}-05)\end{array}$ & $\begin{array}{c}-0.000852^{* * *} \\
(3.09 \mathrm{e}-05)\end{array}$ & $\begin{array}{c}-0.000852 * * * \\
(3.09 \mathrm{e}-05)\end{array}$ & $\begin{array}{c}-0.000852^{* * * *} \\
(3.09 \mathrm{e}-05)\end{array}$ & $\begin{array}{c}-0.000852 * * * \\
(3.09 \mathrm{e}-05)\end{array}$ \\
\hline Dif_Child under age 18 & $\begin{array}{c}-0.000243^{* * *} \\
(3.19 \mathrm{e}-05)\end{array}$ & $\begin{array}{c}-0.000243^{* * *} \\
(3.19 \mathrm{e}-05)\end{array}$ & $\begin{array}{c}-0.000243 * * * \\
(3.19 \mathrm{e}-05)\end{array}$ & $\begin{array}{c}-0.000243^{* * *} \\
(3.19 \mathrm{e}-05)\end{array}$ & $\begin{array}{c}-0.000243^{* * *} \\
(3.19 \mathrm{e}-05)\end{array}$ & $\begin{array}{c}-0.000243^{* * *} \\
(3.19 \mathrm{e}-05)\end{array}$ & $\begin{array}{c}-0.000243 * * * \\
(3.19 \mathrm{e}-05)\end{array}$ \\
\hline Dif_- ${ }^{\text {st }}$ Stage Residuals & $\begin{array}{l}-0.000070 \\
(6.10 \mathrm{e}-05)\end{array}$ & $\begin{array}{l}-0.000051 \\
(6.06 e-05)\end{array}$ & $\begin{array}{l}-0.000055 \\
(6.07 e-05)\end{array}$ & $\begin{array}{l}-0.000061 \\
(6.09 \mathrm{e}-05)\end{array}$ & $\begin{array}{l}-0.000055 \\
(6.07 e-05)\end{array}$ & $\begin{array}{l}-0.000057 \\
(6.10 \mathrm{e}-05)\end{array}$ & $\begin{array}{l}-0.000052 \\
(6.07 \mathrm{e}-05)\end{array}$ \\
\hline Constant & $\begin{array}{c}0.00239 * * * \\
(3.68 \mathrm{e}-05)\end{array}$ & $\begin{array}{c}0.00238 * * * \\
(3.68 \mathrm{e}-05)\end{array}$ & $\begin{array}{c}0.00239^{* * *} \\
(3.68 \mathrm{e}-05)\end{array}$ & $\begin{array}{c}0.00239 * * * \\
(3.69 \mathrm{e}-05)\end{array}$ & $\begin{array}{c}0.00239 * * * \\
(3.68 \mathrm{e}-05)\end{array}$ & $\begin{array}{c}0.00239 * * * \\
(3.69 \mathrm{e}-05)\end{array}$ & $\begin{array}{c}0.00238^{* * *} \\
(3.68 \mathrm{e}-05)\end{array}$ \\
\hline Observations & $6,692,941$ & $6,692,941$ & $6,692,941$ & $6,692,941$ & $6,692,941$ & $6,692,941$ & $6,692,941$ \\
\hline
\end{tabular}

${ }^{\text {a }}$ One * indicates significant at the 10 percent level; two at $5 \%$ level; three at $1 \%$ level. See Section 4.4 .2 of the text for further descrption of these models. 
Table A-2b: Linear Probability Model of Locating in the Same Neighborhood Cluster Controlling for Person Attributes and Residuals from Table $5 b^{a}$ (Robust standard errors in parentheses)

\begin{tabular}{|c|c|c|c|c|c|c|c|}
\hline \multicolumn{8}{|c|}{ PANEL A - MEN } \\
\hline & Gender & Child & Gen-Educ & Gen-Child & $\begin{array}{c}\text { Gen } \\
\text { Mar-Child }\end{array}$ & $\begin{array}{c}\text { Gen } \\
\text { Ed-Child }\end{array}$ & $\begin{array}{l}\text { Gen-Mar } \\
\text { Ed-Child }\end{array}$ \\
\hline & (1) & (2) & (3) & (4) & $(5)$ & (6) & (7) \\
\hline Dif_HS degree/some college & $\begin{array}{c}-0.000228 * * * \\
(4.04 \mathrm{e}-05)\end{array}$ & $\begin{array}{c}-0.000228^{* * *} \\
(4.04 \mathrm{e}-05)\end{array}$ & $\begin{array}{c}-0.000228^{* * *} \\
(4.04 \mathrm{e}-05)\end{array}$ & $\begin{array}{c}-0.000228^{* * *} \\
(4.04 \mathrm{e}-05)\end{array}$ & $\begin{array}{c}-0.000228^{* * *} \\
(4.04 \mathrm{e}-05)\end{array}$ & $\begin{array}{c}-0.000228^{* * *} \\
(4.04 \mathrm{e}-05)\end{array}$ & $\begin{array}{c}-0.000228 * * * \\
(4.05 \mathrm{e}-05)\end{array}$ \\
\hline Dif_BA degree or more & $\begin{array}{c}-0.000724 * * * \\
(3.94 \mathrm{e}-05)\end{array}$ & $\begin{array}{c}-0.000724 * * * \\
(3.94 \mathrm{e}-05)\end{array}$ & $\begin{array}{c}-0.000724 * * * \\
(3.94 \mathrm{e}-05)\end{array}$ & $\begin{array}{c}-0.000724 * * * \\
(3.94 \mathrm{e}-05)\end{array}$ & $\begin{array}{c}-0.000724 * * * \\
(3.94 \mathrm{e}-05)\end{array}$ & $\begin{array}{c}-0.000724 * * * \\
(3.94 \mathrm{e}-05)\end{array}$ & $\begin{array}{c}-0.000722^{* * *} \\
(3.95 \mathrm{e}-05)\end{array}$ \\
\hline Dif_Married & $\begin{array}{c}-0.000817 * * * \\
(3.75 \mathrm{e}-05)\end{array}$ & $\begin{array}{c}-0.000817 * * * \\
(3.75 \mathrm{e}-05)\end{array}$ & $\begin{array}{c}-0.000817 * * * \\
(3.75 \mathrm{e}-05)\end{array}$ & $\begin{array}{c}-0.000817 * * * \\
(3.75 \mathrm{e}-05)\end{array}$ & $\begin{array}{c}-0.000817 * * * \\
(3.75 \mathrm{e}-05)\end{array}$ & $\begin{array}{c}-0.000817 * * * \\
(3.75 \mathrm{e}-05)\end{array}$ & $\begin{array}{c}-0.000823 * * * \\
(3.76 \mathrm{e}-05)\end{array}$ \\
\hline Dif_Child under age 18 & $\begin{array}{c}-0.000190 * * * \\
(3.81 \mathrm{e}-05)\end{array}$ & $\begin{array}{c}-0.000190 * * * \\
(3.81 \mathrm{e}-05)\end{array}$ & $\begin{array}{c}-0.000190 * * * \\
(3.81 \mathrm{e}-05)\end{array}$ & $\begin{array}{c}-0.000190 * * * \\
(3.81 \mathrm{e}-05)\end{array}$ & $\begin{array}{c}-0.000190 * * * \\
(3.81 \mathrm{e}-05)\end{array}$ & $\begin{array}{c}-0.000190 * * * \\
(3.81 \mathrm{e}-05)\end{array}$ & $\begin{array}{c}-0.000187 * * * \\
(3.82 \mathrm{e}-05)\end{array}$ \\
\hline Dif_ $1^{\text {st }}$ Stage Residuals & $\begin{array}{c}-0.000209^{* *} \\
(8.29 \mathrm{e}-05)\end{array}$ & $\begin{array}{c}-0.000199 * * \\
(8.29 \mathrm{e}-05)\end{array}$ & $\begin{array}{c}-0.000209 * * \\
(8.31 \mathrm{e}-05)\end{array}$ & $\begin{array}{c}-0.000211^{* *} \\
(8.30 \mathrm{e}-05)\end{array}$ & $\begin{array}{c}-0.000210^{* *} \\
(8.30 \mathrm{e}-05)\end{array}$ & $\begin{array}{c}-0.000203^{* *} \\
(8.29 \mathrm{e}-05)\end{array}$ & $\begin{array}{c}-0.000209 * * \\
(8.32 \mathrm{e}-05)\end{array}$ \\
\hline Constant & $\begin{array}{c}0.00262 * * * \\
(4.22 \mathrm{e}-05)\end{array}$ & $\begin{array}{c}0.00262 * * * \\
(4.22 \mathrm{e}-05)\end{array}$ & $\begin{array}{c}0.00262 * * * \\
(4.23 \mathrm{e}-05)\end{array}$ & $\begin{array}{c}0.00262 * * * \\
(4.22 \mathrm{e}-05)\end{array}$ & $\begin{array}{c}0.00262 * * * \\
(4.23 \mathrm{e}-05)\end{array}$ & $\begin{array}{c}0.00262 * * * \\
(4.22 \mathrm{e}-05)\end{array}$ & $\begin{array}{c}0.00262 * * * \\
(4.23 \mathrm{e}-05)\end{array}$ \\
\hline Observations & $5,033,350$ & $5,033,350$ & $5,033,350$ & $5,033,350$ & $5,033,350$ & $5,033,350$ & $5,016,312$ \\
\hline \multicolumn{8}{|c|}{ PANEL B - WOMEN } \\
\hline & Gender & Child & Gen-Educ & Gen-Child & $\begin{array}{c}\text { Gen } \\
\text { Mar-Child }\end{array}$ & $\begin{array}{c}\text { Gen } \\
\text { Ed-Child }\end{array}$ & $\begin{array}{l}\text { Gen-Mar } \\
\text { Ed-Child }\end{array}$ \\
\hline & $(1)$ & (2) & (3) & (4) & $(5)$ & (6) & (7) \\
\hline Dif_HS degree/some college & $\begin{array}{c}-0.000191 * * * \\
(3.34 \mathrm{e}-05)\end{array}$ & $\begin{array}{c}-0.000191 * * * \\
(3.34 \mathrm{e}-05)\end{array}$ & $\begin{array}{c}-0.000191^{* * * *} \\
(3.34 \mathrm{e}-05)\end{array}$ & $\begin{array}{c}-0.000191 * * * \\
(3.34 \mathrm{e}-05)\end{array}$ & $\begin{array}{c}-0.000191^{* * *} \\
(3.34 \mathrm{e}-05)\end{array}$ & $\begin{array}{c}-0.000191 * * * \\
(3.34 \mathrm{e}-05)\end{array}$ & $\begin{array}{c}-0.000191 * * * \\
(3.34 \mathrm{e}-05)\end{array}$ \\
\hline Dif_BA degree or more & $\begin{array}{c}-0.000360 * * * \\
(3.32 \mathrm{e}-05)\end{array}$ & $\begin{array}{c}-0.000359^{* * *} \\
(3.32 \mathrm{e}-05)\end{array}$ & $\begin{array}{c}-0.000359^{* * *} \\
(3.32 \mathrm{e}-05)\end{array}$ & $\begin{array}{c}-0.000360^{* * *} \\
(3.32 \mathrm{e}-05)\end{array}$ & $\begin{array}{c}-0.000360^{* * *} \\
(3.32 \mathrm{e}-05)\end{array}$ & $\begin{array}{c}-0.000360 * * * \\
(3.32 \mathrm{e}-05)\end{array}$ & $\begin{array}{c}-0.000359^{* * *} \\
(3.32 \mathrm{e}-05)\end{array}$ \\
\hline Dif_Married & $\begin{array}{c}-0.000853 * * * \\
(3.09 \mathrm{e}-05)\end{array}$ & $\begin{array}{c}-0.000852 * * * \\
(3.09 \mathrm{e}-05)\end{array}$ & $\begin{array}{c}-0.000852 * * * \\
(3.09 \mathrm{e}-05)\end{array}$ & $\begin{array}{c}-0.000853 * * * \\
(3.09 \mathrm{e}-05)\end{array}$ & $\begin{array}{c}-0.000853^{* * *} \\
(3.09 \mathrm{e}-05)\end{array}$ & $\begin{array}{c}-0.000853^{* * *} \\
(3.09 \mathrm{e}-05)\end{array}$ & $\begin{array}{c}-0.000852^{* * *} \\
(3.09 \mathrm{e}-05)\end{array}$ \\
\hline Dif_Child under age 18 & $\begin{array}{c}-0.000243 * * * \\
(3.19 \mathrm{e}-05)\end{array}$ & $\begin{array}{c}-0.000243 * * * \\
(3.19 \mathrm{e}-05)\end{array}$ & $\begin{array}{c}-0.000243 * * * \\
(3.19 \mathrm{e}-05)\end{array}$ & $\begin{array}{c}-0.000243 * * * \\
(3.19 \mathrm{e}-05)\end{array}$ & $\begin{array}{c}-0.000243 * * * \\
(3.19 \mathrm{e}-05)\end{array}$ & $\begin{array}{c}-0.000243^{* * *} \\
(3.19 \mathrm{e}-05)\end{array}$ & $\begin{array}{c}-0.000243^{* * *} \\
(3.19 \mathrm{e}-05)\end{array}$ \\
\hline Dif_ $1^{\text {st }}$ Stage Residuals & $\begin{array}{l}-0.000075 \\
(6.11 \mathrm{e}-05)\end{array}$ & $\begin{array}{l}-0.000065 \\
(6.12 \mathrm{e}-05)\end{array}$ & $\begin{array}{l}-0.000060 \\
(6.10 \mathrm{e}-05)\end{array}$ & $\begin{array}{l}-0.000082 \\
(6.16 \mathrm{e}-05)\end{array}$ & $\begin{array}{l}-0.000068 \\
(6.11 \mathrm{e}-05)\end{array}$ & $\begin{array}{l}-0.000073 \\
(6.15 \mathrm{e}-05)\end{array}$ & $\begin{array}{l}-0.000059 \\
(6.10 \mathrm{e}-05)\end{array}$ \\
\hline Constant & $\begin{array}{c}0.00239 * * * \\
(3.69 \mathrm{e}-05)\end{array}$ & $\begin{array}{c}0.00239 * * * \\
(3.69 \mathrm{e}-05)\end{array}$ & $\begin{array}{c}0.00239 * * * \\
(3.69 \mathrm{e}-05)\end{array}$ & $\begin{array}{c}0.00239 * * * \\
(3.70 \mathrm{e}-05)\end{array}$ & $\begin{array}{c}0.00239^{* * *} * \\
(3.69 \mathrm{e}-05)\end{array}$ & $\begin{array}{c}0.00239 * * * \\
(3.70 \mathrm{e}-05)\end{array}$ & $\begin{array}{c}0.00239 * * * \\
(3.69 \mathrm{e}-05)\end{array}$ \\
\hline Observations & $6,692,941$ & $6,692,941$ & $6,692,941$ & $6,692,941$ & $6,692,941$ & $6,692,941$ & $6,692,941$ \\
\hline
\end{tabular}

${ }^{\text {a }}$ One * indicates significant at the 10 percent level; two at $5 \%$ level; three at $1 \%$ level. See Section 4.4 .2 of the text for further descrption of these models. 